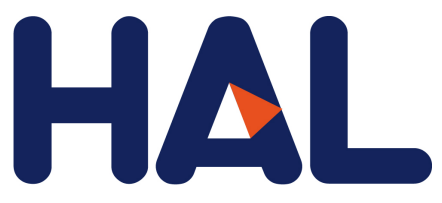

archives-ouvertes

\title{
Annual phytoplankton succession results from niche-environment interaction
}

\author{
Mariarita Caracciolo, Gregory Beaugrand, Pierre Hélaouët, Francois Gevaert, \\ Martin Edwards, Fabrice Lizon, Loïck Kléparski, Eric Goberville
}

\section{To cite this version:}

Mariarita Caracciolo, Gregory Beaugrand, Pierre Hélaouët, Francois Gevaert, Martin Edwards, et al.. Annual phytoplankton succession results from niche-environment interaction. Journal of Plankton Research, Oxford University Press (OUP), 2021, 43 (1), pp.85-102. 10.1093/plankt/fbaa060 . hal03267611

\section{HAL Id: hal-03267611 \\ https://hal.sorbonne-universite.fr/hal-03267611}

Submitted on 22 Jun 2021

HAL is a multi-disciplinary open access archive for the deposit and dissemination of scientific research documents, whether they are published or not. The documents may come from teaching and research institutions in France or abroad, or from public or private research centers.
L'archive ouverte pluridisciplinaire HAL, est destinée au dépôt et à la diffusion de documents scientifiques de niveau recherche, publiés ou non, émanant des établissements d'enseignement et de recherche français ou étrangers, des laboratoires publics ou privés. 


\section{Annual phytoplankton succession results from niche-environment} interaction

Mariarita Caracciolo ${ }^{1}$, Grégory Beaugrand ${ }^{2,3,4}$, Pierre Helaouët ${ }^{4}$, François Gevaert ${ }^{3}$, Martin Edwards ${ }^{4,5}$, Fabrice Lizon ${ }^{3}$, Loïck Kléparski ${ }^{2,3,4}$ Eric Goberville ${ }^{6}$.

Corresponding authors: Mariarita Caracciolo (mariarita.caracciolo@sb-roscoff.fr) and Gregory Beaugrand (Gregory.Beaugrand@univ-lille.fr) 


\section{Abstract}

29 Annual plankton succession has been investigated for many decades and hypotheses ranging from 30 abiotic to biotic mechanisms have been proposed to explain this recurrent pattern. Here, using data 31 collected by the Continuous Plankton Recorder (CPR) survey and models originating from the 32 MacroEcological Theory on the Arrangement of Life (METAL), we investigate annual 33 phytoplankton succession in the North Sea at a species level. Our results show that this 34 phenomenon can be well predicted by models combining photosynthetically active radiation, 35 temperature and macro-nutrients. Our findings suggest that annual phytoplankton succession, at 36 community level, originates from the interaction between species ecological niche and annual 37 environmental fluctuations. We discuss our results in the context of traditional hypotheses 38 formulated to explain this recurrent pattern in the marine field, including those on the initiation, 39 the development and the termination of a typical extratropical spring bloom.

41 Keywords

42 Annual plankton succession, phenology, ecological niche, environment, plankton, Continuous 43 Plankton Recorder (CPR), METAL theory. 
Annual Plankton Succession (APS) is defined as the recurrent pattern of species abundance observed during the annual cycle (Cushing 1959, Winder and Cloern 2010, Sommer et al. 2012, Romagnan et al. 2015). In temperate and polar biomes, phytoplankton abundance varies from periods of proliferation in spring and autumn to periods of decline in summer and winter. In subtropical and tropical waters, where seasonal changes in solar radiation and temperature are less prominent, plankton abundance is more stable at an annual scale (Dakos et al. 2009). In the Mediterranean Sea, eukaryotic primary producers appear from early spring with the following sequence: pico-eukaryotes, silicoflagellates, diatoms and dinoflagellates (Romagnan et al. 2015).

APS has been widely described in marine ecosystems, leading to a variety of potential explanations often based on mechanisms such as bottom-up to top-down controls (Sverdrup 1953, Margalef 1978, Sommer et al. 1986, Behrenfeld 2010, Sommer et al. 2012, Smyth et al. 2014, Romagnan et al. 2015, Atkinson et al. 2018). Gilbert et al. (2012), Romagnan et al. (2015) and Barton et al. (2015) have provided evidence for a strong influence of the physical environment on phytoplankton dynamics, suggesting a bottom-up control of annual succession. A substantial impact of species interaction (i.e. grazing) imposing a top-down control (e.g. mesozooplankton species on protists) has also been suggested in the western part of the English Channel, however (Kenitz et al. 2017, Fileman et al. 2010).

The seasonal cycles of irradiance, temperature and stratification and the associated changes in pycnocline, thermocline and halocline are known to be closely associated with the onset of phytoplankton growth (Longhurst 1998), and nutrients influence the extent of the phytoplankton bloom (Sommer et al. 2012). Although APS starts typically by the onset of the spring bloom in most extra-tropical regions, winter is a key period preparing the ingredients needed to trigger the start of phytoplankton proliferation (Sommer et al. 2012). During winter, oceans and seas lose heat from their surface waters, which become denser and consequently start to sink (Mann and Lazier 1996). Wind intensifies oceanic turbulence, which in turn brings nutrients (nitrate, phosphate and silicic acid) in the euphotic zone (Falkowski and Oliver 2007) while diluting phytoplankton in the water column (Behrenfeld 2010).

According to the Sverdrup's model (Sverdrup 1953), the spring phytoplankton bloom can develop when the Mixed Layer Depth (MLD), which can reach several hundred meters in the North Atlantic Ocean during winter (Reygondeau and Beaugrand 2010), is shallower than a critical depth at which the integral of net growth rate becomes zero over the water column. Sverdrup's theory has greatly stimulated research and this hypothesis is applicable to both deep waters and off-shore environments but not in shallow coastal systems (Behrenfeld 2010, Sathyendranah et al. 2015, Lévy 2015). The intensity of the phytoplankton bloom is strengthened when solar heating and reduced winds increase vertical stratification, leading to a strong thermocline. Irradiance is an important factor due to its influence on critical depth and vernal stratification, allowing species to remain in the euphotic zone. It has also been observed that the phytoplankton bloom sometimes starts before water stratification, which has led some authors to challenge Sverdrup's concept (Behrenfeld 2010). For instance, the dilution-recoupling hypothesis from Behrenfeld (2010) explains how the spring phytoplankton bloom is the result of an increase in growth at a time of strong dilution of grazers in the water column due to the absence of stratification. Progressive stratification during the bloom reinforces the coupling between phytoplankton and grazers, and 
the reduction in nutrients availability - combined to a high grazing pressure - induces bloom termination. When the mixed layer deepens and increases macro-nutrients concentration in the euphotic zone, an autumn phytoplankton bloom can occur (Longhurst 1998); it ends rapidly, however, because of light limitation (Sverdrup 1953, Geider et al. 2014).

The main objective of this study is to reconstruct APS using models of increasing complexity

\section{MATERIALS AND METHODS}

\subsection{Biological data}

Biological data originated from the Continuous Plankton Recorder (CPR, https://www.cprsurvey.org/data/our-data/) survey. This marine biological monitoring programme, currently operated by the Marine Biological Association (MBA), has sampled the North Atlantic Ocean and its adjacent seas on a routine monthly basis since 1946 at a depth of approximately 7 10 meters (Reid et al. 2003). Data from this programme have been extensively used to (i) investigate APS (e.g., Colebrook 1979, 1982c, Zhai et al. 2013, Barton et al. 2015), (ii) characterise pelagic biodiversity (e.g., Beaugrand et al. 2002, Barnard et al. 2004), (iii) document distributional, phenological and physiological responses of marine species to climate change (e.g., Helaouët and Beaugrand 2009, Beaugrand et al. 2009, Thackeray et al. 2016, Beaugrand and Kirby, 2018) and (iv) anticipate the consequences of global warming in the pelagic realm (e.g., Reid et al. 1998, Beaugrand et al. 2015). 
In this study, we restricted our analyses to phytoplankton communities in the North Sea $\left(1^{\circ} \mathrm{E}\right.$ $-4^{\circ} \mathrm{E}$ and $54^{\circ} \mathrm{N}-56^{\circ} \mathrm{N}$; Fig. S1) and considered 90 species or taxa commonly monitored by the CPR survey over the period 1946-2016 (Table S1). The area was chosen because it was regularly sampled over the last decades and is located relatively far from the coastline. In the selected area and for all selected taxa, we calculated a climatology for each Julian day (i.e. 365) by averaging the selected taxa abundances over the period 1958-2016.

\subsection{Environmental data}

Nutrients data originated from the World Ocean Atlas 2013 V2, provided by NOAA National Centers for Environmental Information (NCEI), Silver Spring, Maryland, USA (https://www.nodc.noaa.gov/OC5/woa13/woa13data.html) (Locarnini et al. 2013). It is a scientifically quality-controlled database of selected historical in situ surface and subsurface oceanographic measurements for phosphate $\left(\mu \mathrm{mol} . \mathrm{L}^{-1}\right)$, silicate $\left(\mu \mathrm{mol} . \mathrm{L}^{-1}\right)$ and nitrate $\left(\mu \mathrm{mol} . \mathrm{L}^{-}\right.$ $\left.{ }^{1}\right)$. Monthly means are provided for these three parameters, on a $3 \mathrm{D}$ grid of $1^{\circ}$ latitudes by $1^{\circ}$ longitude by 37 depth levels. Here, we calculated the average nutrients concentration in the North Sea $\left(1^{\circ} \mathrm{E}-4^{\circ} \mathrm{E}\right.$ and $54^{\circ} \mathrm{N}-56^{\circ} \mathrm{N}$; Fig. S1) for the first $20 \mathrm{~m}$. From this dataset, we calculated the N/P ratio (Redfield 1958), which is known to modulate APS (Falkowski et al. 2000).

We used the Photosynthetically Active Radiation (PAR; Einstein . $\mathrm{m}^{-2}$. day ${ }^{-1}$ ), solar radiation spectrum in the wavelength range of $400-700 \mathrm{~nm}$, as a proxy of the level of energy that can be assimilated by photosynthetic organisms (Asrar, Myneni \& Kanemasu, 1989). PAR regulates both the composition and evolution of marine ecosystems, influencing the growth of phytoplankton and in turn the development of zooplankton and fish. Data were provided by the Giovanni online data system, developed and maintained by the NASA GES DISC (http://gdata1.sci.gsfc.nasa.gov/daacbin/G3/gui.cgi?instance id=ocean_month). A monthly climatology of PAR at a spatial resolution of $9 \mathrm{~km}$ was carried out by compiling data of the Sea-viewing Wide Field-of-view Sensor (SeaWiFS) from 2009 to 2012.

Because of the well-known influence of temperature (Beaugrand et al. 2018), we assessed the thermal environment of the 90 phytoplankton species over our region of interest using Sea Surface Temperature (SST) from the Optimum Interpolation (OI), which is based on both in situ and satellite observations (see Reynolds et al. 2002 for a full description of the OI analysis). In contrast to other environmental data which were only available at a monthly resolution, we used daily SST for a finer estimation of the thermal preferendum of species. We first calculated daily SSTs on a $1^{\circ}$ by $1^{\circ}$ grid from January 1982 to December 2017 and data were then averaged in the area ranging from $1^{\circ} \mathrm{E}$ to $4^{\circ} \mathrm{E}$ and from $54^{\circ} \mathrm{N}$ to $56^{\circ} \mathrm{N}$ (Fig. S1). Annual changes in the environmental parameters are shown in Fig. 1.

\subsection{Examination of APS from the CPR survey}

First, we removed species that had average annual abundance $<0.5$ in the target area (Table S1, Fig. S1). This procedure led to the selection of 81 phytoplankton species (Table S1) for which we estimated average daily abundances over the region of interest for the period 1946-2015. To minimise short-term fluctuations and reduce the noise inherent to these data, we applied an order6 symmetrical moving average on each daily time series (Legendre and Legendre 1998).

A standardised Principal Component Analysis (PCA; Jolliffe 1986) was applied on the correlation matrix 81 phytoplankton species x 365 days and the first three principal components 
(PCs) were examined to identify changes in annual succession. Species were then sorted according to their phenology by using normalised eigenvectors, i.e. linear correlation values with the corresponding PCs higher than $|0.5|$ (Table S1). Only significative axes (PCs) were represented (Fig. 2).

Finally, we clustered phytoplankton species into five groups: Bacillariophyceae, Dinophyceae, Primnesiophyceae, Dictyochophyceae and Cyanophyceae.

\subsection{Generation of pseudo-species using models from the METAL theory}

We modeled patterns of APS using METAL (Beaugrand et al. 2014, 2018). First, we generated a pool of uni-dimensional niches (i.e., niches with only one ecological dimension) by using a Gaussian model (Ter Braak 1996):

$$
A=c e^{-\left(\frac{\left(x-x_{o p t}\right)^{2}}{2 t^{2}}\right)}
$$

where $\mathrm{A}$ is the abundance of a species as a function of the value of a given environmental parameter $\mathrm{x}$; $\mathrm{c}$ is the maximum abundance of a pseudo-species with $\mathrm{c}$ being fixed to 1 (Beaugrand, 2015); $x_{\text {opt }}$ is the environmental optimum (e.g. the best environmental condition for a given species that can reach the highest level of abundance) and $t$ is the ecological amplitude of a pseudo-species (i.e. the environmental range where a species can occur) for a given environmental factor (Table S3). Species abundance along environmental gradients is generally modelled using a Gaussian model (Gauch et al. 1974).

Multi-dimensional niches (i.e., niches with 2 or more ecological dimensions) were modelled as follows:

$$
A=C e^{-\frac{1}{2}}\left[\left(\frac{x_{1}-x_{\text {opt } 1}}{t_{1}}\right)^{2}+\cdots+\left(\frac{x_{n}-x_{o p t n}}{t_{n}}\right)^{2}\right]
$$

with $2 \leq \mathrm{n} \leq 5$ ecological dimensions, $x_{1}$ to $x_{n}$ the values of the environmental parameters, $x_{o p t 1}$ to $x_{o p t n}$, the optimum values of $x_{1}$ to $x_{n}$, and $t_{1}$ to $t_{n}$, the ecological amplitudes of $x_{1}$ to $x_{n}$.

Our simulations were based upon six environmental parameters: (i) SST, (ii) PAR, (iii) nitrate, (iv) phosphate, (v) silicate, and (vi) N/P ratio. When the N/P ratio was considered, neither nitrate nor phosphate concentrations were included in the models to avoid possible bias related to multicollinearity. We performed simulations using all possible environmental combinations from one to five ecological dimensions (Table S2), leading to a total of 84 runs (i.e. simulations): 16 uni-dimensional runs, 23 two-dimensional runs, 29 three-dimensional runs, 13 four-dimensional runs and 3 five-dimensional runs (Table S2). The characteristics (optimum and ecological amplitude) of all niches are presented in Table S3. For example, for temperature, we defined 7 optimum values (i.e. values corresponding to the highest abundance for a given pseudo-species) ranging from 0 to $36^{\circ} \mathrm{C}$ by increment of $6^{\circ} \mathrm{C}$ and 4 ecological amplitudes from 1 to $10^{\circ} \mathrm{C}$ by increment of $3^{\circ} \mathrm{C}$, leading to the creation of 28 (4 x 7) virtual (or pseudo-) niches.

For each run, a large number of niches (from 21 to 15,431,472) was created (Table S3). To determine the total number of niches per run, we multiplied the number of niches generated for a 
given dimension by the number generated for all other ecological dimensions. For example, for a run based on temperature, PAR and nitrate (i.e. a three-dimensional run), the total number of niches was $28 \times 21 \times 27=15,876$ ecological niches (with 28 niches for SST, 21 for PARc and 27 for nitrate; Table S3).

To test whether the resolution of niches (i.e. the number of points along the niches) affected our analyses, we compared two extreme cases of uni-dimensional models (i.e. low and high resolutions) using each ecological variable. We added the term "bis" after the name of the variable to identify high-resolution niche (Tables S3-S4). When the word 'bis' was absent, the unidimensional niche had a low resolution. Because of the high number of categories generated in the high-resolution case (e.g. 144,648,000 categories for a run based on temperature bis, PARa bis and phosphate bis), we did not perform high-resolution analyses based on more than one dimension because of calculation time estimated to be $\sim 4$ months on a high-performance computer of 88 cores.

To examine the sensitivity of our analyses to low PAR values, we considered three minimum values: 1 (termed "PARa", Table S3), 10 ("PARb") and 20 ("PARc") E.m"-day'.

Finally, annual estimations of pseudo-species abundances were assessed by performing a cubic interpolation of the 1-5D niches with the corresponding environmental variables. Four runs on APS are closely examined as examples: (i-iii) three uni-dimensional runs based on either (i) SST, (ii) PAR or (iii) nitrate (Fig. 3) and (iv) one three-dimensional run based on SST, PAR and nitrate (Fig. 4).

\subsection{Comparisons of predicted and observed seasonal patterns}

Comparisons between predicted and observed annual patterns in phytoplankton abundance were performed in two ways. First, we calculated the coefficient of linear correlation (Pearson's correlation coefficient; Fig. 5 and Fig. S3). Second, we used the Mean Absolute Error (MAE; Fig. S3) that measures the average magnitude of the errors in a set of predictions, without considering their direction.

$$
M A E=\sum_{i=1}^{n} \frac{|X i-Y i|}{n}
$$

with $\mathrm{n}$ the number of differences to be tested, $X_{i}$ is prediction $i$ and $Y_{i}$ is observation $i$. Equation (3) represents the absolute differences between predictions and observations, divided by the number of differences to be tested (with all individual differences having equal weight). It is a negatively-oriented score, which means that the lower values are related to the strongest correlations.

Pearson's correlation coefficients and MAEs were calculated for each run between all observed and predicted daily patterns in (pseudo-) species abundance, leading to a correlation or MAE matrix $\mathrm{u} \times \mathrm{v}$ (species $\mathrm{x}$ pseudo-species). We then identified the highest positive correlations and the lowest MAE values. For each run, we therefore obtained two vectors using the average correlation and MAE values calculated for each species (Fig. S4). The daily normalised (between 0 and 1) pseudo-species abundances that showed the highest correlation with observed species were plotted against daily observed species abundances to graphically depict the relationships (Fig. 5).

We then tested both correlations and MAEs using null models that considered (or not) temporal autocorrelation. First, we randomly generated a number of daily time series 
corresponding to the total number of pseudo-species generated for each run. Although the number of time series was small for 1D runs, it became important when the number of dimensions increased as we multiplied the number of niches per parameter. The procedure was repeated 1000 times and, for each simulation, the average correlation and MAE values were calculated. To consider temporal autocorrelation, we generated two million of time series and kept the first 1000 with a 30-order (i.e., 30 days/ one-month autocorrelation for daily time series) autocorrelation higher than average 30 -order autocorrelation found in observed daily time series. We represented the results in a diagram that exhibited the observed average correlation for each run and the 1000 correlations found using the null model with (red) and without (blue) autocorrelation (Fig. S3). For each combination of environmental variables (i.e. 84 runs), we calculated the probability of significance of each correlation (Table S4). Finally, we used contour diagrams to identify (i) the most important environmental parameters and (ii) the number of dimensions to accurately reconstruct APS. This graphical examination allowed us to highlight the number of species that exhibits the highest correlations in each run (Fig. 6).

3. RESULTS

\subsection{Seasonal changes in environmental parameters in the North Sea}

Temperature exhibited a minimum at the beginning of March and a maximum at the end of July-August (Fig. 1). PAR showed minimum and maximum values in December-January and June, respectively. The highest concentrations in nitrate, phosphate and silicate were observed in winter and reached their lowest concentrations from the end of spring to the end of summer. Except for SST, no variation was captured within a given month because monthly means were used for all other parameters.

\subsection{Observed annual phytoplankton succession}

We examined APS based on CPR plankton data by means of a PCA (Fig. 2). The use of the first three principal components allowed us to differentiate five periods, each being characterised by a species assemblage: (i) an early-spring stage (Fig. $2 \mathrm{~b}$ left part of the panel, 8 species negatively correlated to PC1), (ii) a spring stage (Fig. 2c, 22 species positively correlated to PC2), (iii) a widespread summer stage (Fig. 2a, 28 species positively related to PC1), (iv) a late summer/beginning of autumn stage (Fig. 2d, 13 species negatively correlated to PC3) and (v) an autumn stage (Fig. $2 \mathrm{~b}$ right part of the panel, 8 species negatively correlated to PC1). The summer stage (Fig. 2a) was characterised by the highest species richness, but showed a low proportion of diatoms in comparison to both spring or autumn stages; silicoflagellates were also present (Table S1). Other principal components were not represented because they did not bring additional information.

\subsection{Modelled annual phytoplankton succession}

We reconstructed APS by using models of growing complexity (i.e., by considering a growing number of niche dimensions) including all combinations of SST, PAR, nitrate, phosphate, silicate and N/P ratio (a total of 84 runs). Here, we focused on four examples of modelled APS reconstructed by using different ecological dimensions (Fig. 3 and 4). The first run, based on SST only, showed two main phases of high phytoplankton abundance (also representative of a high species richness) in summer (Fig. 3a) and winter (Fig. 3b) and two minor phases in spring (Fig. 
3c) and autumn (Fig. 3c). The winter phase of high abundance did not correspond to any observed patterns (Fig. 2 versus Fig. 3). The second run, based on PAR only, showed several peaks of high phytoplankton abundance in spring, summer and autumn (Fig. 3d-f). These patterns were close to observed patterns of annual succession (Fig. 2), suggesting an important role of PAR in the modulation of APS. The third model, based on nitrate only (Fig. 3g-i), showed an important winter peak in phytoplankton abundance, not detected in the observations (Fig. 2 versus 3 ). This result suggests that considering nitrate only was not sufficient to reconstruct APS. The fourth model, that combined SST, PAR and nitrate (Fig. 4a-e), was more efficient to reproduce APS observed in the CPR data, especially the late-summer phase (Fig. 4 versus Fig. 2). A closer examination of the relationships between predicted and observed APS is performed below.

\subsection{Relationships between observed and modelled annual phytoplankton succession}

\subsubsection{Reconstruction of species seasonal patterns}

We calculated the Pearson's correlation coefficients between observed and simulated (pseudo-) species for all 84 runs; we remind here that our runs were characterised by a growing number of ecological dimensions - ranging from one to five - and that all combinations $(C=84)$ of environmental parameters were tested. We chose the best correlations and examined graphically the relationships between observed and predicted phytoplankton abundances (Fig. 5). Figure 5 shows all the relationships between phytoplankton species considered in the analyses and pseudospecies created from METAL. For all phytoplankton groups, simulated pseudo-species reproduced observed seasonal patterns well: most annual phytoplankton patterns in observed and simulated phytoplankton species were closely related (e.g., Skeletonema costatum and Thalassiosira spp.) with the exception of Paralia sulcata and Dactyliosolen antarcticus (Fig. 5). Correlation and MAE values are examined in detail in the following sections.

\subsubsection{Identification of key ecological dimensions to reconstruct APS}

To identify key ecological dimensions, we calculated the average of the best correlations and MAEs between observed and simulated (pseudo-) species for all 84 runs (Table S4, Fig. S3). We tested our correlations and MAEs using a null model with and without consideration for temporal autocorrelation. While some MAE values were significant for some 1D runs (Fig.S3), APS was better reproduced when at least three dimensions were considered (Fig. S3). Not all correlations were significant for models based on three or more ecological dimensions while considering five dimensions did not improve the percentage of explained variance (i.e. model quality). This suggests that the selection of relevant environmental variables is more important than considering a too high number of ecological dimensions.

\subsubsection{Identification of key environmental variables to reconstruct APS}

We then identified the most relevant environmental parameters and the number of ecological dimensions that best reproduce APS (Fig. 6). We remind here that APS is the result of species phenology (i.e., species seasonal patterns). Uni-dimensional models (1D, Runs 1-16) explained poorly observed seasonal changes in species abundance, with the exception of Run 2 that was exclusively based on SST (Fig. 6a); for Run 2, eight species showed their highest correlations between observed and modelled seasonal patterns. Bi-dimensional models (Runs 17-39) also explained poorly species seasonal patterns and only 3 species exhibited their highest correlations when the model was based on both temperature and PAR (Fig. 6a, Table S2). Better results were 
achieved when models were based on three or more ecological dimensions. Three-dimensional models (Runs 40-68) had 29 highest correlations between observed and modelled seasonal patterns (Fig. 6a). Run 51 based on SST, N/P and PARc (i.e., a minimum value of PAR=20 E.m ${ }^{-2}$.day ${ }^{-1}$ ) exhibited 10 highest correlations. Four-dimensional (Runs 69-81) and five-dimensional models (Runs 82-84) had 25 and 14 highest correlation values, respectively.

We also examined the correlations between each simulated and observed seasonal patterns for all species and runs (Fig. 6b). The figure showed that even if best results were achieved for models based on SST only (Run 2), results were similar when three or more dimensions were included. Low correlations generally appeared when the triplet SST/PAR/macro-nutrient was not used (Fig. $6 \mathrm{~b}$ and Table S2, e.g., Runs 53-56), revealing that the combination of these variables was important to reproduce most species seasonal patterns.

\section{DISCUSSION}

\subsection{Annual phytoplankton succession}

The METAL theory suggests that large-scale patterns in biodiversity emerged from the niche-environment interactions that propagate from the species to the community level (Beaugrand et al. 2013b, Beaugrand et al. 2015, Beaugrand et al. 2018). Here, our results show that APS including the spring bloom - may also originate from the niche-environment interaction (Fig. 5). APS has been frequently investigated at the group level (e.g. plankton functional type, plankton ecology groups or categories). However, our study shows that even within a given ecological or taxonomic group, species reacts to environmental fluctuations individually through the nicheenvironment interaction, conforming themselves to the principle of species individuality (Whittaker 1975) (Fig. 5). Our study therefore suggests that it is important to investigate APS by exploring ecological patterns and processes at a species level.

Our results show a prominent control of APS by environmental conditions in the North Sea. Studying APS in the Mediterranean Sea, Romagnan et al. (2015) have also provided evidence for a strong control of the physical environment on APS. Even though our modelling approach reproduced well the seasonal cycle of eight species when based on SST only, better results were achieved when three or more ecological dimensions were considered (Fig. 6). Considering five dimensions did not improve substantially the percentage of explained variance, probably because seasonal changes in nitrate, phosphate and silicate concentrations are highly correlated in the North Sea.

Our investigation of APS revealed four main microphytoplanktonic succession in the North Sea (see Table S1 for a list of the species considered in our study). The first assemblage is composed of species that exhibited their highest abundance at the beginning of spring and a second less important peak in autumn (PC1 in Fig. 2b, Fig. 5). This microphytoplanktonic assemblage, generally composed of large diatoms (Table S1 and Fig. 5, e.g. Thalassionema nitzschioides, Ditylum brightwellii), was primarily controlled by PAR and nutrients availability in our models. PAR is an essential parameter limiting photosynthesis and its influence on growth rate is well known (Eppley \& Sloan, 1966). PAR is a strong limiting factor in areas above the polar circle (McMinn \& Martin, 2013) but also in lower latitude regions such as the North Sea (Peeters et al. 
1993). Nutrients positively influenced growth rate and primary production (Goldman 1980, Longhurst 1998). The first assemblage is also psychrophilic, reaching its highest abundance when temperature is lowest and their lowest abundance when temperature is highest (Fig. 1). The assemblage is not detected when PAR is highest and when PAR or nutrients concentration is lowest (Fig. 1). Although not considered in our analyses, turbulence, mixing and high SST variability that characterise early spring and autumn may also positively influence the occurrence of this assemblage, which is more adapted to such an environment than dinoflagellates (Beaugrand et al. 2010, Holligan et al. 1980, Margalef 1978). In winter, PAR (or the number of daily light hours) and to a lesser extent temperature limit diatom growth and deep-water column mixing combined to an absence of biological production enable nutrients to increase at the sea surface.

The second assemblage (e.g. Chaetoceros spp., Coscinodiscus concinnus) occurs generally between April and June at a time when silicate and to a lesser extent nitrate and phosphate concentrations diminish and temperature and PAR increase (Fig. 1, 2c and 5). This assemblage is less psychrophile than the first one and occur at a time when both temperature and PAR increase (Fig. 1).

The third assemblage is composed of species, mainly dinoflagellates (e.g. Ceratium fusus and $C$. furca) and some small diatoms (e.g. Guinardia striata, G. flaccida), occurring when temperature and PAR are high and conditions are oligotrophic (Fig. 1, 2a and 5). Silicate depletion played an important role in the change of dominance observed between the second and the third assemblage. In a mesocosm experiment, silicate deficiency was assumed to be the cause of the strong reduction in large spring bloom diatoms and the replacement by flagellates (Jacobsen et al. 1995). Small diatoms need less silicic acid for the their skeleton and have a higher surface to volume ratio which increases nutrient absorption (Miller, 2004). Dinoflagellates occur in areas and at time when both temperatures are warm, SST variability low and the water column is well stabilised (Beaugrand et al. 2010, Margalef 1978).

The fourth assemblage is composed of species (e.g. the diatom Bellerochea malleus, Biddulphia alternans) having their occurrence from August to October (Fig. 2d and 5). Those species occur when temperature is high and when nutrients concentration tends to increase. Those warm-temperate species have their northern limit of spatial distribution in the North Sea (e.g. Bellerochea malleus)(Barnard et al. 2004).

Despite the fact that four main microphytoplanktonic successions were identified by the PCA, many intermediate situations occur (Fig. 5). For example, some species (e.g. Rhizosolenia setigera) exhibit a higher abundance when PAR are above $10 \mathrm{E} \cdot \mathrm{m}^{-2}$.day ${ }^{-1}$ but show a diminution when temperature is high and conditions are oligotrophic (Fig. 5). A summer reduction is sometimes not observed for species occurring between spring and autumn (e.g. Gyrosigma spp.). Some species have a peak in late spring and another smaller one in autumn (e.g. Dactyliosolen fragilissimus). Others have a small peak in spring and a high one in autumn (e.g. Leptocylindrus danicus). Many species have narrow seasonal peaks not identified by the PCA (e.g. Asteromphalus spp., Ceratium buceros, C. carriense). Because most observed patterns in annual abundance were well reconstructed by our approach, it is likely that APS may result from the niche-environment interaction (Fig. 5). Sharp or gradual environmental gradients interact with the niche of each species within a multidimensional space to generate a variety of phenological patterns (Fig. 5). 
The application of the Plankton Ecology Group (PEG) model in lakes and subsequently in the marine realm (Sommer et al. 1986, Sommer et al. 2012) has suggested that (i) physics (light and stratification) controls the start and the end of the phytoplankton growth season, (ii) grazing by metazoan plankton results in a clear water phase, (iii) nutrients define the carrying capacity of phytoplankton, (iv) food limitation determines zooplankton abundances and (v) fish predation determines zooplankton size structure. The PEG model has emphasised the role of physical factors, grazing and nutrient limitation for phytoplankton. Our results have shown the key role of bottomup processes in shaping APS and recall the importance of considering a combination of several environmental factors, not only light. PAR and to a lesser extent SST, are important for the initiation of the spring bloom, macronutrients for the end of the spring bloom and both SST and macronutrients for the development of APS. Light (e.g. PAR, photoperiod), nutrients and temperature are seen as master parameters controlling photosynthesis in physiological studies (Geider et al. 1997, Longhurst 1998, McMinn \& Martin 2013, Ras et al. 2013). While grazing may have a substantial influence (Kivi et al. 1993, Fileman et al. 2010, Kenitz et al. 2017), the absence of grazing consideration in our analyses did not prevent us to accurately reconstruct species phenology (Fig. 5).

\subsection{The spring bloom}

Our study also provides evidence for a strong environmental control of the initiation, development and termination phases of the spring bloom although processes are distinct from those formulated by Gran and Braarud (Gran and Braarud 1935) and Sverdrup (1953). The Critical Depth Theory (Sverdrup 1953) proposed that spring blooms in regions close to the North Atlantic Drift Provinces develop when the Mixed Layer Depth (MLD) becomes shallower than the critical depth (i.e., blooming can occur when MLD is less than the critical value), which was derived analytically as a function of the amount of incoming radiation, water transparency and the energy level at the compensation depth (i.e., the depth at which gross photosynthesis balances phytoplankton respiration). According to the CDT, bloom initiation is only possible in spring in high latitudes.

The possibility that the onset of the spring phytoplankton bloom occurs as a consequence of decreased zooplankton grazing pressure has recently been proposed by Behrenfeld (2010). Our models suggest that neither the occurrence of a MLD shallower than the critical depth nor a dilution effect resulting from the occurrence of a deep MLD is necessary to reproduce bloom initiation and more generally species phenology in the investigated North Sea region. The integration of PAR - and to a lesser extent SST - in the models simply explained the initiation of the spring bloom in the North Sea. Average light intensity in the mixed layer is well-known to govern the timing of the spring bloom (Riley 1967; Legendre 1990), even if phytoplankton production losses due to mixing may also be important (Behrenfeld 2010). Some studies have also reported that spring bloom may occur in the absence of water stratification (Townsend et al. 1992), confirming that phytoplankton initiation may precede the establishment of a clear thermocline (Colebrook 1979). Revisiting the dilution-recoupling hypothesis (Behrenfeld 2010), Beaugrand (2015) has also suggested PAR as a key driver of bloom initiation (his figure 5.27). Smyth and colleagues (2014) have conveyed that the spring bloom started in the western part of the English Channel (Station L4, Plymouth) when net heat flux becomes positive. Because net heat flux is highly positively related to irradiance and PAR (Beaugrand 2015), a strong control of PAR on the initiation of the spring bloom may be expected. 
Our models also suggest that the limitation in macro-nutrients is a key factor for bloom termination, which is only in partial agreement with the Sverdrup and the Behrenfeld hypotheses. To model the end of the spring bloom, we did not have to include grazing (Sverdrup 1953) or a coupling between grazers and phytoplankton (Behrenfeld 2010). Instead, the low macro-nutrients concentrations could explain alone bloom termination. As earlier, we do not state that grazing has not an effect, but we suggest that the physical environment is an important driver. Large seasonal changes in atmospheric forcing and ocean surface conditions shape, to a great degree, the seasonal cycles of phytoplankton biomass, but also the relative abundance of phytoplankton species (Barton et al. 2014). Beaugrand (2015) showed that phytoplankton and zooplankton seasonal fluctuations were closely related in the North Atlantic region investigated by Behrenfeld (his figure 5.28), suggesting a "bottom-up" control. More recently, Atkinson and colleagues (2018) demonstrated that both the increase and termination of the spring bloom are encapsulated by zooplankton, providing strong evidence against a top-down control.

Although the succession between diatoms and dinoflagellates can be well explained by macro-nutrients and temperature in our models, it is well-known since Margalef (1979) that water column stability is a key factor to explain the succession between these two functional groups. Dinoflagellates are more sensitive than diatoms to turbulence (Karp-Boss et al. 2000). They can realise significant vertical migration to nutrient rich area but cannot reproduce when turbulence is too high (Estrada and Berdalet 1997). In contrast, diatoms can continue cell division and the photosynthetic energy products are used to synthetize fatty acid that are converted to energy when cells are exported below the euphotic zone; fatty acid can be considered as a buoyancy regulator (Amato et al. 2017). It is possible that mixing and turbulence are not required in our models because temperature is a proxy of mixing and turbulence conditions in the North Sea. Confirmation of our results should be searched in other regions experiencing different sequences of environmental conditions.

\subsection{Uncertainties related to our approach}

The niche-environment interaction is certainly more unpredictable in the field than in our modelling approach for two main reasons. First, while the fundamental niche (sensu Hutchinson) was estimated here, the environment - through random meteorological conditions - may influence the realised niche of microalgae species. Second, phytoplankton community before and/or during the growth of a given species may alter species realised niche by competition for resources that lead to competitive exclusion. The trait-based approach of Breton et al. (2017) suggests that competitive exclusion prevails during Phaeocystis spp. bloom.

It is well-known that the underwater light available for photosynthesis (PAR) is a key environmental variable for primary production (Cole and Cloern 1987, MacIntyre et al. 2000, Foden et al. 2010, Capuzzo et al. 2013, 2015, 2018). Light field in the water column depends in turn on phytoplankton biomass (self-shading), inorganic suspended particulate materials, colored dissolved organic materials and water itself (IOCCG 2000). Recent works on light quality have also revealed the important role of spectral irradiance on phytoplankton succession (Lawrenz and Richardson 2017). In this study, we used surface PAR data that originated from a climatology. All phytoplankton species can perform photo-regulation or photo-acclimation (i.e., the first occurs at time scales of minutes and the second takes place in a few hours or a day) to limit photo-inhibition in high light surface waters or optimise both light harvesting and Calvin cycle activity in the water column (MacIntyre et al. 2000, Lavaud 2007, Dubinsky and Stambler 2009). In addition, photo- 
acclimation processes can be conducted on different kinetic models and time scales (Cullen and Lewis 1988), according to environmental conditions and functional phytoplankton groups (MacIntyre et al. 2000). Even if photosynthesis performances between different species remain poorly documented (Goss et Lepetit 2015, Suggett et al. 2015), they can induce a competitive effect between species at a given time.

\section{CONCLUSIONS}

Our study suggests that APS may result from the niche-environment interaction. Our model

\section{Acknowledgements}

The CPR Survey is an internationally funded charity that operates the CPR programme. The CPR survey operations and routes are funded by a funding consortium from the UK, USA, Canada and Norway. Within the UK, government organisations DEFRA and NERC contribute to core operations. Part of this research was funded by the Centre National de la Recherche Scientifique (CNRS). This research was funded as part of the ANR TROPHIK.

\section{References}

Amato, A., Dell'Aquila, G., Musacchia, F., Annunziata, R., Ugarte, A., Maillet, N., Carbone, A., Ribera d'Alcalà, M., Sanges, R., Iudicone, R., and Ferrante, M. 2017. Marine diatoms change their gene expression profile when exposed to microscale turbulence under nutrient replete conditions. Scientific Report 3826, 1-11.

Asrar, G., Myneni, R. B., Li, Y., and Kanemasu, E. T. (1989). Measuring and modeling spectral characteristics of a tallgrass prairie, Remote Sens. Environ. 27:143-155.

Assis, J., Tyberghein, L., Bosh S., Verbruggen, H., Serrão, E.A., De Clerck, O. 2017. BioORACLE v2.0: Extending marine data layers for bioclimatic modelling. Global Ecology and Biogeography 27, 277-84.

Atkinson, A., Polimene, L., Fileman, E.S., Widdicombe, C.L., McEvoy, A.J., Smyth, T.J., Djeghri, N., Sailley, S.F., Cornwell, L.E.. 2018. What drives plankton seasonality in a stratifying shelf 
sea? Some competing and complementary theories. Limnology and Oceanography 9999, 17.

Barnard, R., Batten, S. D., Beaugrand, G., Buckland, C., Conway, D. V. P., Edwards, M., Finlayson, J., Gregory, L. W., Halliday, N. C., John, A. W. G., Johns, D. G., Johnson, A. D., Jonas, T. D., Lindley, J. A., Nyman, J., Pritchard, P., Reid, P. C., Richardson, A. J., Saxby, R. E., Sidey, J., Smith, M. A., Stevens, D. P., Taylor, C. M., Tranter, P. R. G., Walne, A. W., Wootton, M., Wotton, C. O. M., and Wright, J. C. 2004. Continuous plankton records: plankton atlas of the North Atlantic Ocean (1958-1999). II. Biogeographical charts. Marine Ecology Progress Series Supplement, 11-75.

Barton, A. D., Lozier, M. S., and Williams, R. G. 2015. Physical controls of variability in North Atlantic phytoplankton communities. Limnology and Oceanography 60, 181-197.

Beaugrand, G., Reid, P. C., Ibañez, F., Lindley, J. A. and Edwards, M. 2002. Reorganization of North Atlantic marine copepod biodiversity and climate. Science 296, 1692-1694.

Beaugrand, G., Luczak, C., and Edwards, M. 2009. Rapid biogeographical plankton shifts in the North Atlantic ocean. Global Change Biology 15, 1790-1803.

Beaugrand, G., Edwards, M., and Legendre, L. 2010. Marine biodiversity, ecosystem functioning and the carbon cycles. Proceedings of the National Academy of Sciences 107, 10120-10124. Beaugrand, G., Mackas, D., and Goberville, E. 2013a. Applying the concept of the ecological niche and a macroecological approach to understand how climate influences zooplankton: advantages, assumptions, limitations and requirements. Progress in Oceanography 111, 7590.

Beaugrand, G., Rombouts, I., and Kirby, R. R. 2013b. Towards an understanding of the pattern of biodiversity in the oceans. Global Ecology and Biogeography 22, 440-449.

Beaugrand, G., Goberville, E., Luczak, C., Kirby, R.R. 2014. Marine biological shifts and climate. Proceedings of the Royal Society B: Biological Sciences 281, 20133350.

Beaugrand, G. 2015. Marine biodiversity, climatic variability and global change. London: Routledge.

Beaugrand, G., Edwards, M., Raybaud, V., Goberville, E., Kirby, R.R. 2015. Future vulnerability of marine biodiversity compared with contemporary and past changes. Nature Climate Change 5, 695-70.

Beaugrand, G., 2015. Theoretical basis for predicting climate-induced abrupt shifts in the oceans. Philosophical Tansactions of the Royal Society B: Biological Sciences, 37020130264.

Beaugrand, G., and Kirby, R. R. 2018. How do marine pelagic species respond to climate change? Theories and observations. Annual Review of Marine Science 10, 169-197.

Beaugrand, G., Luczak, C., Goberville, E., Kirby, R.R. 2018. Marine biodiversity and the chessboard of life. Plos One 13, e0194006.

Behrenfeld, M. J. 2010. Abandoning Sverdrup's Critical Depth Hypothesis on phytoplankton blooms. Ecology 91, 977-989.

Breton, E., Christaki, U., Bonato, S., Didry, M., Artigas, L.F. 2017. Functional trait variation and nitrogen use efficiency in temperate coastal phytoplankton. Marine Ecology Progress Series 563, 35-49.

Capuzzo, E., Painting, S. J., Forster, R. M., Greenwood, N., Stephens, D. T. and Mikkelsen, O. A. 2013. Variability in the sub-surface light climate at ecohydrodynamically distinct sites in the North Sea. Biogeochemistry 113, 85-103. 
Capuzzo, E., Stephens, D., Silva, T., Barry, J., and Forster, R. M. 2015. Decrease in water clarity of the southern and central North Sea during the $20^{\text {th }}$ century. Global Change Biology 21, 2206-2214.

Capuzzo, E., Lynam, C., Barry, J., Stephens, D., Forster, R. M., Greenwood, N., McQuattersGollop, A., Silva, T., van Leeuwen, S. M. and Engelhard, G. H. 2018. A decline in primary production in the North Sea over 25 years, associated with reductions in zooplankton abundance and fish stock recruitment. Global Change Biology 24, 352-364.

Cole, B. E., and Cloern, J. E. 1987. An empirical model for estimating phytoplankton productivity in estuaries. Marine Ecology Progress Series 36, 299-305.

Colebrook, J. M. 1979. Continuous Plankton Records: seasonal cycles of phytoplankton and copepods in the North Atlantic Ocean and the North Sea. Marine Biology 51, $23-32$.

Colebrook, J. M. 1982. Continuous Plankton Records: seasonal variations in the distribution and abundance of plankton in the North Atlantic Ocean and the North Sea. Journal of Plankton Research 4, 435-462.

Cullen, J. J., and Lewis, M. R. 1988. The kinetics of algal photoadaptation in the context of vertical mixing. Journal of Plankton Research 10, 1039-1063.

Cushing, D. H. 1959. The seasonal variation in oceanic production as a problem in population dynamics. Journal du Conseil 24, 455-464.

Dakos, V., Beninca, E., van Nes, E.H., Philippart, C.J.M., Scheffer, M., Huisman, J. 2009. Interannual variability in species composition explained as seasonally entrained chaos. Proceedings of the Royal Society B 276, 2871-80.

Dubinsky, Z., and Stambler, N. 2009. Photoacclimation processes in phytoplankton: mechanisms, consequences, and applications. Aquatic Microbial Ecology 56, 163-176.

Eppley, R.W., Sloan P.R., 1966. Growth rates of marine phytoplankton: correlation with light absorption by cell chlorophyll a. Physiologia Plantarum 19, 47-59.

Estrada, M., and Berdalet, E. 1997. Phytoplankton in a turbulent world. Scientia Marina 61, 125140.

Falkowski, P., Scholes, R. J., Boyle, E., Canadell, J., Canfield, D., Elser, J., Gruber, N., Hibbard, K., Högberg, P., Linder, S., Mackenzie, F. T., Moore III, B., Pedersen, T., Rosenthal, Y., Seitzinger, S., Smetacek, V., and Steffen, W. 2000. The global carbon cycle: A test of our knowledge of Earth as a system. Science 290, 291-296.

Falkowski, P. G., and Oliver, M. J. 2007. Mix and max: how climate selects phytoplankton. Nature Reviews Microbiology 5, 813-819.

Fileman, E., Petropavlovsky, A., and Harris, R. 2010. Grazing by the copepods Calanus helgolandicus and Acartia clausi on the protozooplankton community at station L4 in the Western English Channel. Journal of Plankton Research 32, 709-724.

Foden, J., Devlin, M. J., Mills, D. K., and Malcolm, S. J. 2010. Searching for undesirable disturbance: an application of the OSPAR eutrophication assessment method to marine waters of England and Wales. Biogeochemistry 106, 157-175.

Gauch, H. G., Chase, G. B., and Whittaker, R. H. 1974. Ordination of vegetation samples by Gaussian species distributions. Ecology 55, 1382-1390.

Geider, R.J., MacIntyre, H.L., Kana T.M. 1997. A dynamic model of phytoplankton growth and acclimation: responses of the balanced growth rate and chlorophyll a: carbon ratio to light, nutrient-limitation and temperature. Marine Ecology Progress Series, 148, 187-200.

Geider, R. J., C. M. Moore, and D. J. Suggett 2014. Ecology of Marine Phytoplankton. Ecology and the Environment. Springer 1-41. 
Gilbert, J. A., Steele, J. A., Caporaso, J. G., Steinbrück, L., Reeder, J., Temperton, B., and Somerfield, P. J. 2012. Defining seasonal marine microbial community dynamics. The ISME journal 6, 298-308.

Goldman, J. C., 1980. Physiological processes, nutrient availability, and the concept of relative growth rate in marine phytoplankton ecology. Primary Productivity in the Sea, ed. P. G. Falkowski, 179-194. New York: Plenum

Goss, R., and Lepetit, B. 2015. Biodiversity of NPQ. Journal of Plant Physiology 172:13-32.

Helaouët, P., and Beaugrand, G. 2009. Physiology, ecological niches and species distribution. Ecosystems 12, 1235-1245.

Gran, H.H., Braarud, T. 1935. A quantitative study of the phytoplankton in the Bay of Fundy and the Gulf of Maine (including observations on hydrography, chemistry and turbidity). Journal of the Biology Board of Canada, 1 (5), 279-467.

Holligan, P.M., Maddock, L., Dodge, J.D. 1980. The distribution of dinoflagellates around the British Isles in July 1977: a multivariate analysis. Journal of Marine biology Association UK, 60, 851-867.

Huisman, J., van Oostveen, P., and Weissing, F. J. 1999. Critical depth and critical turbulence: two different mechanisms for the development of phytoplankton blooms. Limnology and Oceanography 44, 1781-1787.

Hutchinson, G. E. 1957. Concluding remarks. Cold Spring Harbor Symposium on Quantitative Biology 22, 415-427.

IOCCG. 2000. Remote sensing of ocean colour in coastal, and optically-complex, waters. Reports of the International Ocean-Colour Coordinating Group, $n^{\circ} 3$, edited by S. Sathyendranath, 140, Dartmouth.

Jacobsen A., Egge J.K. and Heimdal B.R. 1995. Effects of increased concentration of nitrate and phosphate during a spring bloom experiment in microcosm. Journal of Experimental Marine Biology and Ecology 187: 239-251.

Jolliffe, I. T. 1986. Principal Component Analysis. Springer-Verlag New York Inc. Springer series in statistics.

Karp-Boss, L., Boss, E., and Jumars, P. A. 2000. Motion of dinoflagellates in simple shear flow. Limnology and Oceanography 45, 1594-1602.

Kenitz, K. , Visser, A., Mariani, P., and Andersen, K. H. 2017. Seasonal succession in zooplankton feeding traits reveals trophic trait coupling. Limnology and Oceanography 62, 1184-1197.

Kivi, K., Kaitala, S., Kuosa, H., Kuparinen, J., Leskinen, E., Lignell, R., Marcussen, B., and Tamrninen, T. 1993. Nutrient limitation and grazing control of the Baltic planktonic community during annual succession. Limnology and Oceanography 38, 893-905.

Lavaud, J. 2007. Fast regulation of photosynthesis in diatoms: Mechanisms, evolution and ecophysiology. Functional Plant Science and Biotechnology 1, 267-287.

Lawrenz, E., and Richardson, T. L. 2017. Differential effects of changes in spectral irradiance on photoacclimation, primary productivity and growth in Rhodomonas salina (cryptophyceae) and Skeletonema costatum (bacillariophyceae) in simulated black water environment. Journal of Phycology 53, 1241-1254.

Legendre, L. 1990. The significance of microalgal blooms for fisheries and for the export of particulate organic carbon in oceans. Journal of Plankton Research 12, 681-699.

Legendre, P., and Legendre, L. 1998. Numerical Ecology. $2^{\text {nd }}$ edition. Elsevier Amsterdam.

Lévy, M. 2015. Exploration of the critical depth hypothesis with a simple NPZ model. ICES Journal of Marine Science 72, 1916-1925. 
Locarnini, R. A., Mishonov, A. V., Antonov, J. I., Boyer, T. P., Garcia, H. E., Baranova, O. K., Zweng, M. M., Paver, C. R., Reagan, J. R., Johnson, D. R., Hamilton, M., and Seidov, D., 2013. World Ocean Atlas, Volume 1: Temperature, edited by: Levitus, S. and Mishonov, A., NOAA Atlas NESDIS 73, 40. Available at: http://data.nodc.noaa.gov/woa/WOA13/DOC/woa13_vol1.pdf.

Longhurst A. 1998. Ecological geography of the sea. Academic Press, London

MacIntyre, H. L., Kana, T. M., and Geider, R. J. 2000. The effect of water motion on shortterm rates of photosynthesis by marine phytoplankton. Trends in Plant Science 5, 12-7.

Mann, K. H., and Lazier, J. R. N. 1996. Dynamics of marine ecosystems: biological-physical interactions in the oceans. $2^{\text {nd }}$ edition. Oxford: Blackwell Science, Incorporated.

Margalef, R. 1978. Life-forms of phytoplankton as survival alternatives in an unstable environment. Oceanologica Acta 1, 493-509.

Margalef, R. 1979. Functional morphology of organisms involved in red tides, as adapted to decaying turbulence. Toxic dinoflagellate blooms, 1:89-94.

McMinn, A., and Martin, A. (2013). Dark survival in a warming world. Proceeding of the Royal Society B Biological Science, 280:20122909.

Miller, J.H. and S. Moser. 2004. Communication and Coordination.Complexity, 9:31-40.

Peeters, J. C. H., Haas H. A., Peperzak L. and de Vries I., 1993. Nutrients and light as factors controlling phytoplankton biomass on the Dutch Continental Shelf (North Sea) in 19881990. Report DGW 93(4). Rijkswaterstaat Tidal Waters division, Middelburg.

Ras, M., Steyer, J.P., Bernard, O. 2013. Temperature effect on microalgae: a crucial factor for outdoor production. Reviews in Environmental Science and Biotechnology 12, 153-164

Reid, P. C., Edwards, M., Hunt, H.G. and Warner, A.J. 1998. Phytoplankton change in the North Atlantic. Nature 391, 546.

Redfield, A. 1958. The biological control of chemical factors in the environment. American Scientist 46, 205-221.

Reid, P. C., Colebrook, J. M., Matthews, J. B. L., Aiken, J., Barnard, R., Batten, S. D., Beaugrand, G., Buckland, C., Edwards, M., Finlayson, J., Gregory, L., Halliday, N., John, A. W. G., Johns, D., Johnson, A. D., Jonas, T., Lindley, J. A., Nyman, J., Pritchard, P., Richardson, A. J., Saxby, R. E., Sidey, J., Smith, M. A., Stevens, D. P., Tranter, P., Walne, A., Wootton, M., Wotton, C. O. M. \& Wright, J. C. 2003. The Continuous Plankton Recorder: concepts and history, from plankton indicator to undulating recorders. Progress in Oceanography 58, $117-173$.

Reygondeau, G., and Beaugrand, G. 2010. Water column stability and Calanus finmarchicus. Journal of Plankton Research 33, 119-136.

Reynolds, R. W., Rayner, N. A., Smith, T. M., Stokes, D. C., and Wang, W. 2002. An improved in situ and satellite SST analysis for climate. Journal of Climate 15, 1609-1625.

Riley, G. A. 1967. The plankton of estuaries. American Association for the Advancement of Science 83, 316-326.

Romagnan, J. B., Legendre, L., Guidi, L., Jamet, J. L., Jamet, D., Mousseau, L., Pedrotti, M. L., Picheral, M., Gorsky, G., Sardet, C., and Stemmann, L. 2015. Comprehensive model of annual plankton succession based on the whole-plankton time series approach. Plos One 10, e0119219.

Sathyendranah, S., Ji, R. and Browman, H. I. 2015. Revisiting Sverdrup's critical depth hypothesis. ICES Journal of Marine Science 72, 1892-1896. 
Smyth T. J., Allen, I., Atkinson, A., Bruun, J.T., Harmer, R.A., Pingree, R. D., Widdicombe, C. E., and Sommerfield, P. 2014. Ocean net heat flux influences seasonal to interannual patterns of plankton abundance. Plos One 9, e98709. DOI:10.1371/journal.pone.0098709.

Sommer U., Gliwicz, Z., Lampert, W., and Duncan, A. 1986. The Peg-Model of seasonal succession of planktonic events in fresh waters. Archive of Hydrobiology 106, 433-471.

Sommer, U., Adrian, R., De Senerpont Domis, L., Elser, J. J., Gaedke, U., Ibelings, B., Jeppesen, E., Lürling, M., Molinero, J. C., Mooij, W. M., van Donk, E., and Winder, M. 2012. Beyond the Plankton Ecology Group (PEG) model: mechanisms driving plankton succession. Annual Review of Ecology, Evolution, and Systematics 43, 429-48.

Suggett, D. J., Goyen, S., Evenhuis, C., Szabo, M., Pettay, D. T., Warner, M. E. and Ralph, P. J. 2015. Functional diversity of photobiological traits within the genus Symbiodinium appears to be governed by the interaction of cell size with cladal designation. New Phytologist 208, 370-381.

Sverdrup, H. U. 1953. On conditions for the vernal blooming of phytoplankton. Journal du Conseil Permanent International pour l'Exploitation de la Mer 18, 287-295.

Ter Braak, C. J. F. 1996. Unimodal models to relate species to environment. Wageningen, DLOAgricultural Mathematics Group.

Thackeray, S. J., Henrys, P. A., Hemming, D., Bell, J. R., Botham, M. S., Burthe, S., Helaouët, P., Johns, D. G., Jones, I. D., Leech, D. I., Mackay, E. B., Massimino, D., Atkinson, S., Bacon, P. J., Brereton, T. M., Carvalho, L., Clutton-Brock, T. H., Duck, C., Edwards, M., Elliott, J. M., Hall, S. J. G., Harrington, R., Pearce-Higgins, J. W., Høye, T. T., Kruuk, L. E. B., Pemberton, J. M., Sparks, T. H., Thompson, P. M., White, I., Winfield, I. J., and Wanless, S. 2016. Phenological sensitivity to climate across taxa and trophic levels. Nature 535, 241245.

Townsend, D. W., Keller, M. D., Sieracki, M. E. \& Ackleson, S. G. 1992. Spring phytoplankton blooms in the absence of vertical water column stratification. Nature 360, 59-62.

Tyberghein, L., Verbruggen, H., Pauly, K., Troupin, C., Mineur, F., De Clerck, O. 2012. BioORACLE: A global environmental dataset for marine species distribution modelling. Global Ecology and Biogeography 21, 272-81.

Widdicombe, C. E., Eloire D., Harbour D., Harris, R. P., and Somerfield, P. J. 2010. Long-term phytoplankton community dynamics in the Western English Channel. Journal of Plankton Research 32, 643-655.

Whittaker, R. H. 1975. Communities and ecosystems, $2^{\text {nd }}$ edition New York: Macmillan.

Winder, M., and Cloern, J. E. 2010. The annual cycles of phytoplankton biomass. Philosophical Transactions of the Royal Society of London B: Biological Sciences 365, 3215-3226.

Zhai, L., Platt, T., Tang, C., Sathyendranath, S., and Walne, A. 2013. The response of phytoplankton to climate variability associated with the North Atlantic Oscillation. Deep Sea Research II Topical Studies in Oceanography 93, 159-168. 
Figure 1. Annual changes in the environmental parameters considered in this study. (a) Sea Surface Temperature (SST), (b) Photosynthetically Active Radiation (PAR), (c) Nitrate, (d) Silicate, (e) and Phosphate concentrations, and (f) Nitrate/Phosphate (N/P) ratio. Note that SST is at a daily resolution whereas other parameters are at a monthly one (see Materials and Methods).

Figure 2. Annual succession of phytoplankton sorted by PCA. (a) Species positively and (b) negatively correlated with the first principal component (PC1). (c) Species positively correlated with PC2. (d) Species negatively correlated with PC3. Only annual changes in phytoplankton species with normalised eigenvectors negatively $(<-0.5)$ or positively $(>0.5)$ correlated to a corresponding principal component were represented. See Table S1 for information on species and their relations to the PCs. Tot. Sp. Richness: total species richness.

Figure 3. Reconstructed annual plankton succession from a one-dimensional model based on SST (Sea Surface Temperature, left panels), PAR (Photosynthetically Active Radiation, middle panels) and nitrate (right panels). A PCA was performed on the relative pseudo-species abundances to identify the most important seasonal phytoplankton abundance patterns. Only predicted plankton seasonal changes, related substantially negatively or positively (i.e., normalised eigenvectors $>|0.5|$ ) to the Principal Components (PCs) are shown. SST (a-c): species (a) positively and (b) negatively correlated to $\mathrm{PC1}$, (c) species negatively correlated to PC2. SST: Individual pseudo-species abundance is on the left vertical axis. PAR (d-f): species (d) positively and (e) negatively correlated to PC1, (f) species negatively correlated to PC2. Nitrate (g-i): species (g) positively and (h) negatively correlated to PC1, (i) species negatively correlated to PC2. Relative individual pseudo-species abundances generated from METAL are on the left vertical axis.

Figure 4. Reconstructed annual plankton succession from a three-dimensional run based on SST, PAR and nitrate. A PCA was performed on relative individual pseudo-species abundances to identify the most important seasonal patterns in phytoplankton abundance. Only predicted plankton seasonal changes related substantially negatively or positively (i.e., normalised eigenvectors $>|0.5|$ ) to the Principal Components (PCs) are shown. Species (a) positively and (b) negatively correlated to PC1. (c) Species negatively correlated to PC2. (d) Species negatively correlated to PC3. (e) Species positively correlated to PC4. Individual pseudo-species abundance is on the left vertical axis.

Figure 5. Seasonal patterns in standardised observed and simulated phytoplankton species abundances. Relative abundances of species sampled by the CPR survey (blue) plotted together with relative abundances of pseudo-species reconstructed using METAL (orange). See Table S1 for species names.

Figure 6. Identification of the key environmental parameters for reconstructing annual phytoplankton succession. (a) Number of phytoplankton species exhibiting their highest correlation for each model (run). See Table S2 for the correspondence between run numbers and environmental combinations of variables. (b) Highest correlation for a given phytoplankton species and run. The colorbar shows the linear correlation value. 

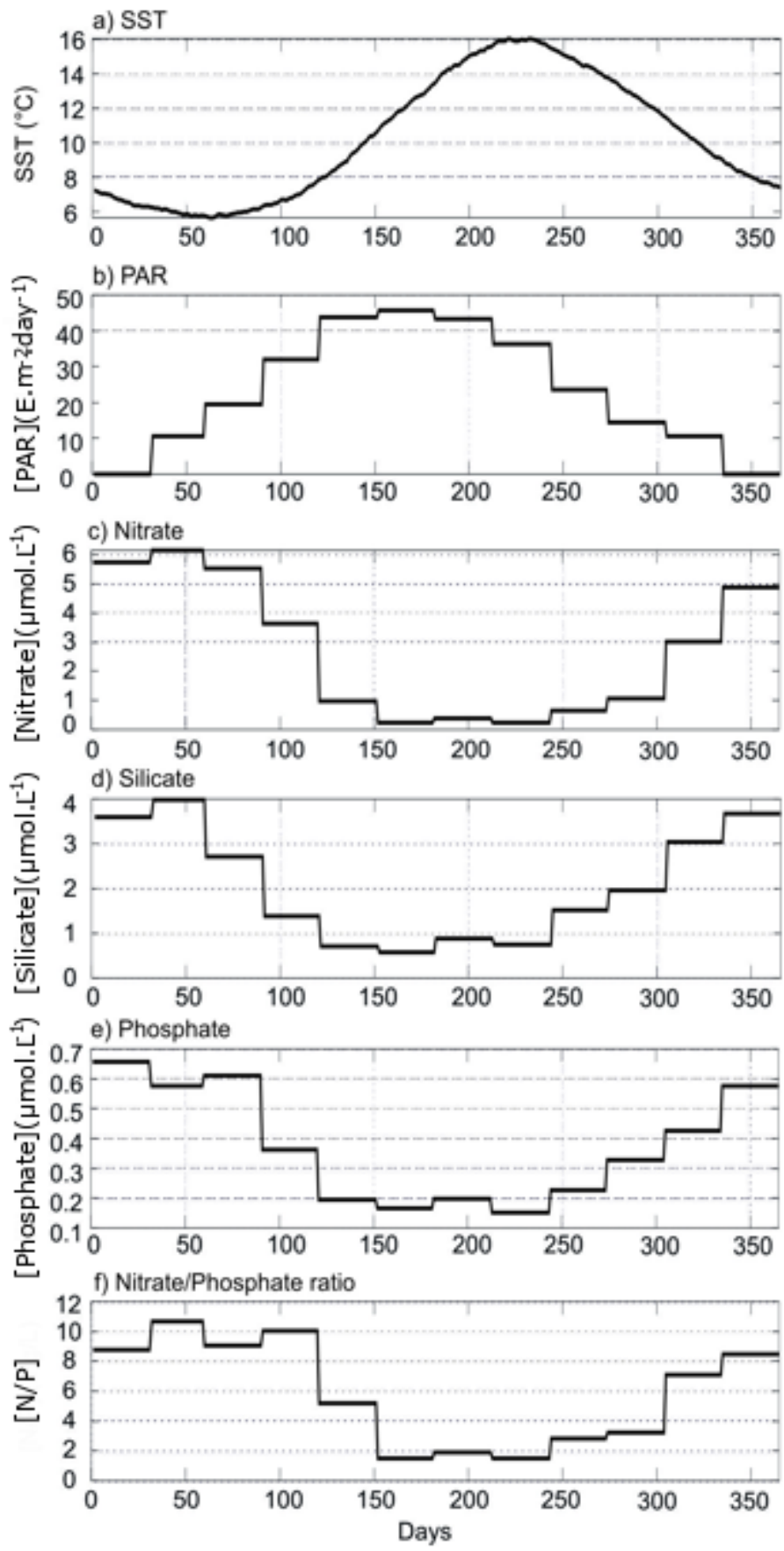

811

812

813 


\section{$814 \quad$ Figure 2.}
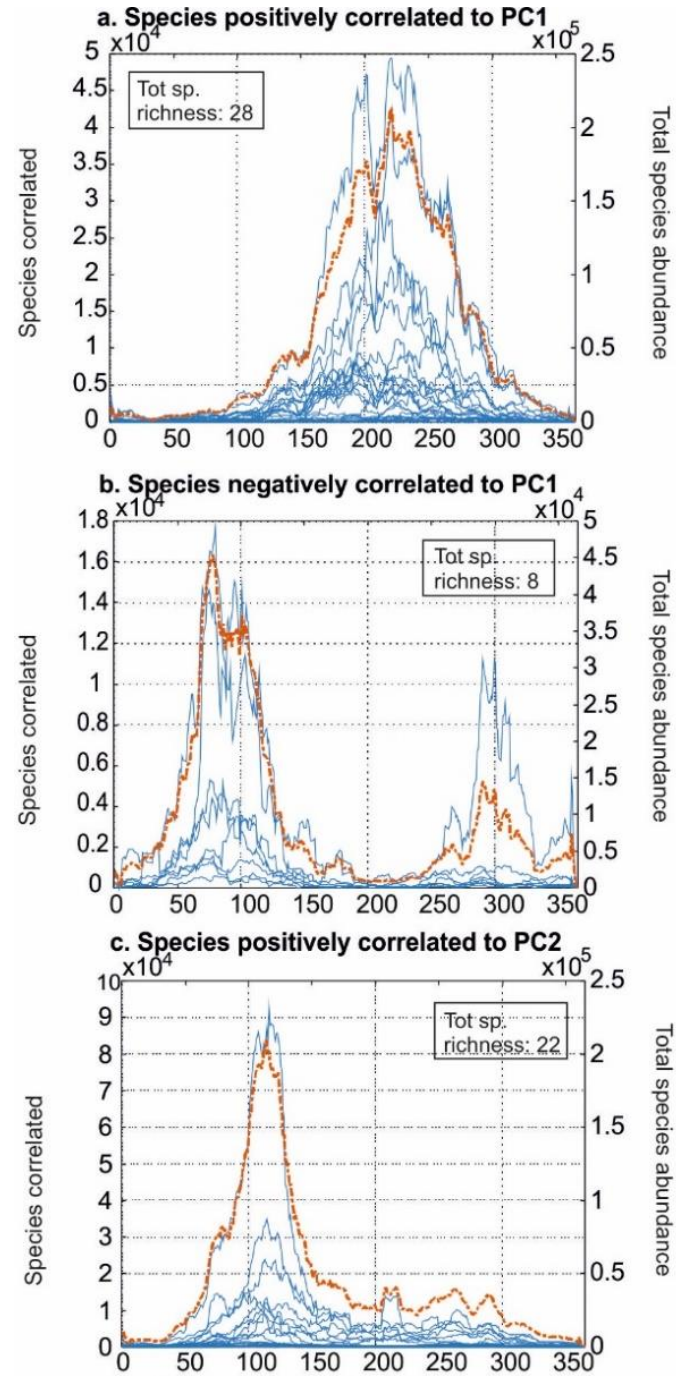

d. Species negatively correlated to $\mathrm{PC} 3$

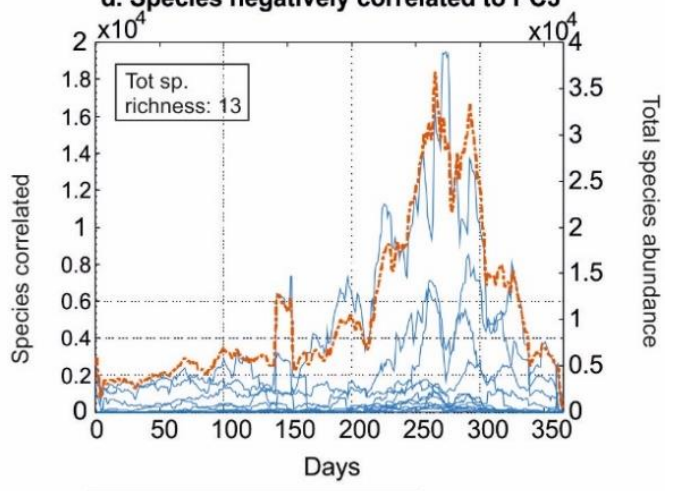

815

Species correlated

to principal component

$\square$ Total species abundance 


\section{Figure 3.}

SST
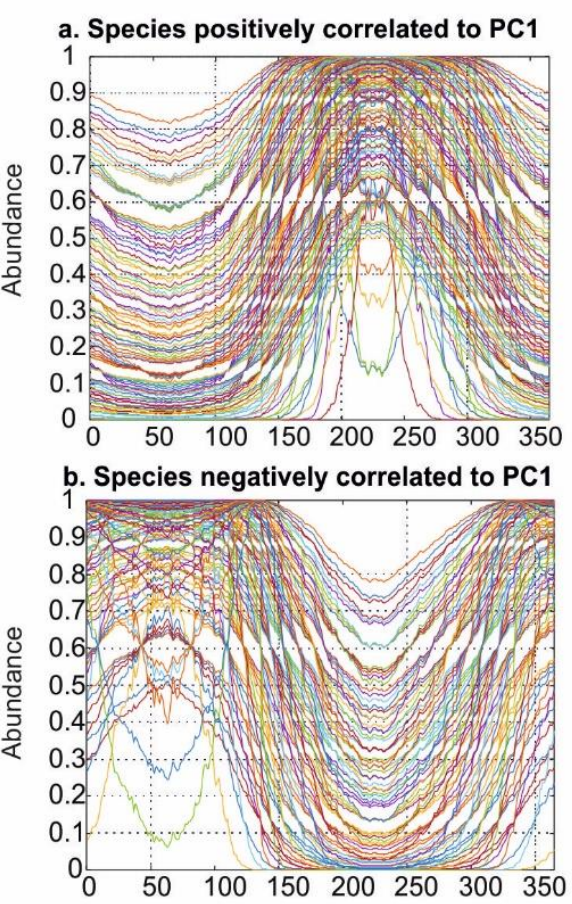

c. Species negatively correlated to PC2

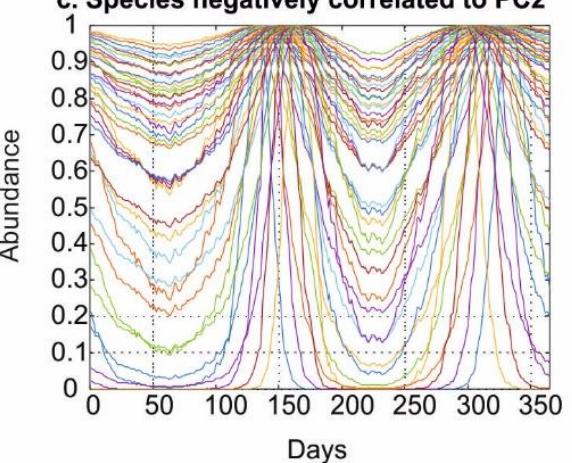

PAR

d. Species positively correlated to PC1

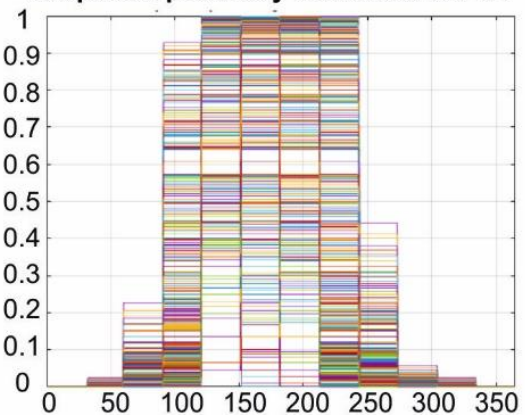

e. Species negatively correlated to PC1

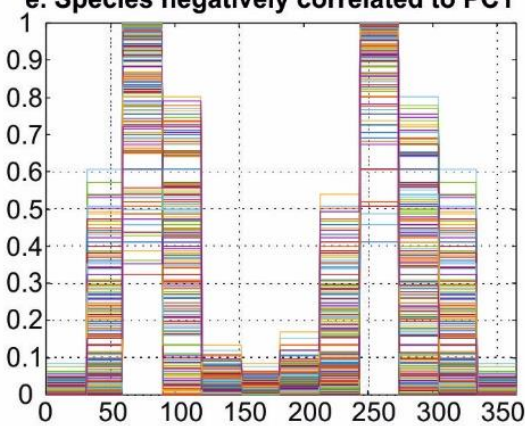

f. Species negatively correlated to PC2

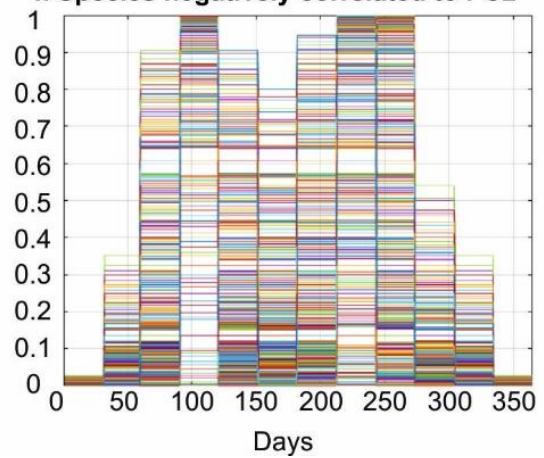

Nitrate
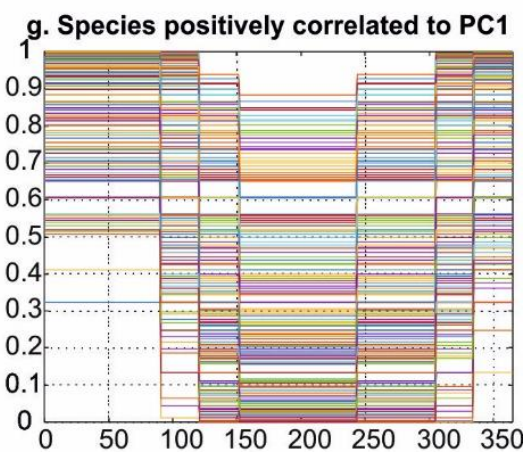

h. Species negatively correlated to PC1

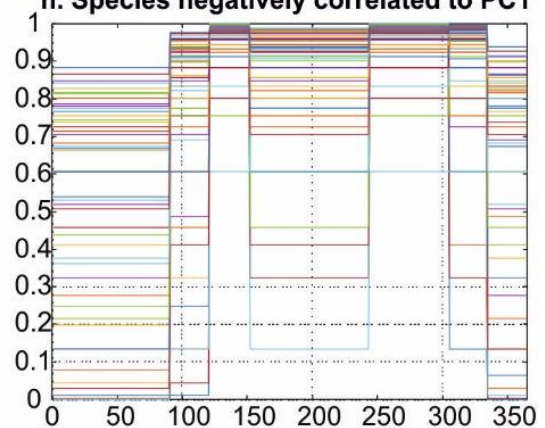

i. Species negatively correlated to PC2

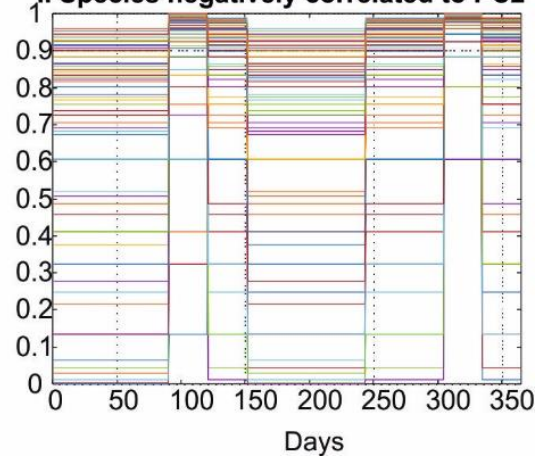




\section{Figure 4.}

a. Species positively correlated to PC1

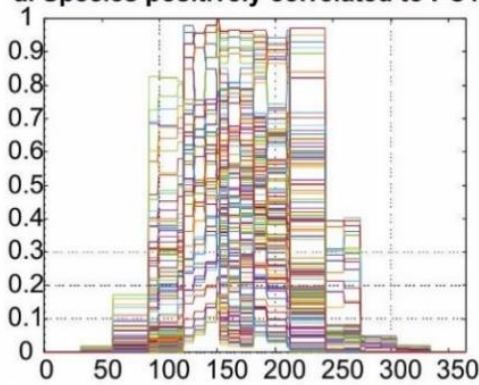

b. Species negatively correlated to PC1
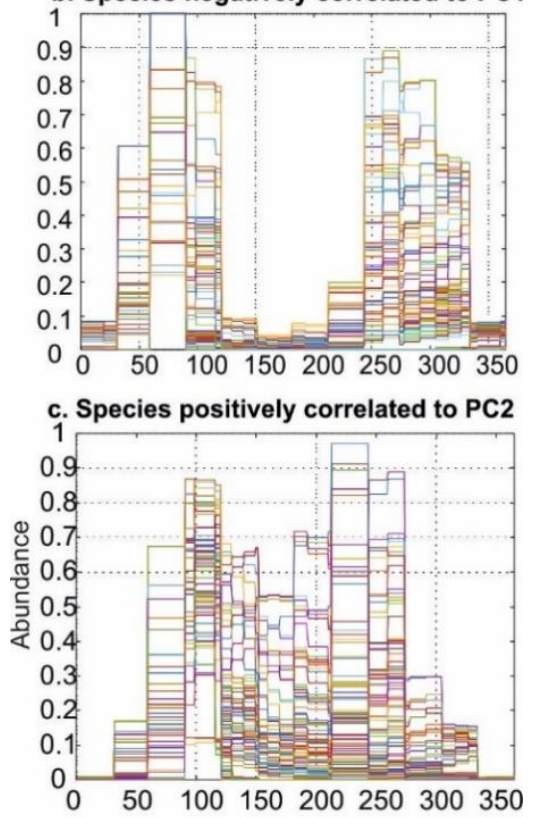

d. Species negatively correlated to PC3

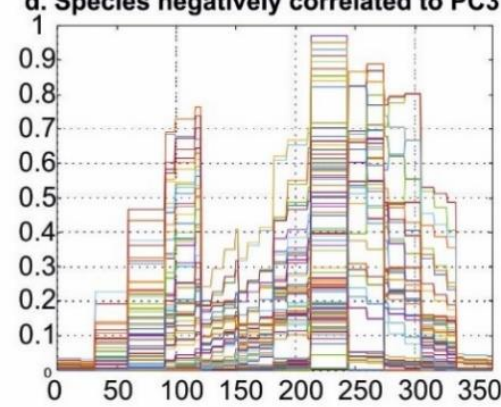

e. Species positively correlated to PC4

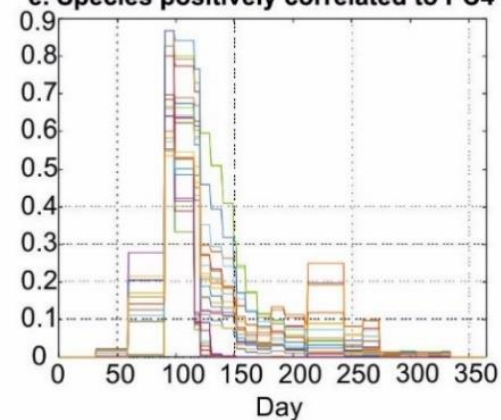


Figure 5.

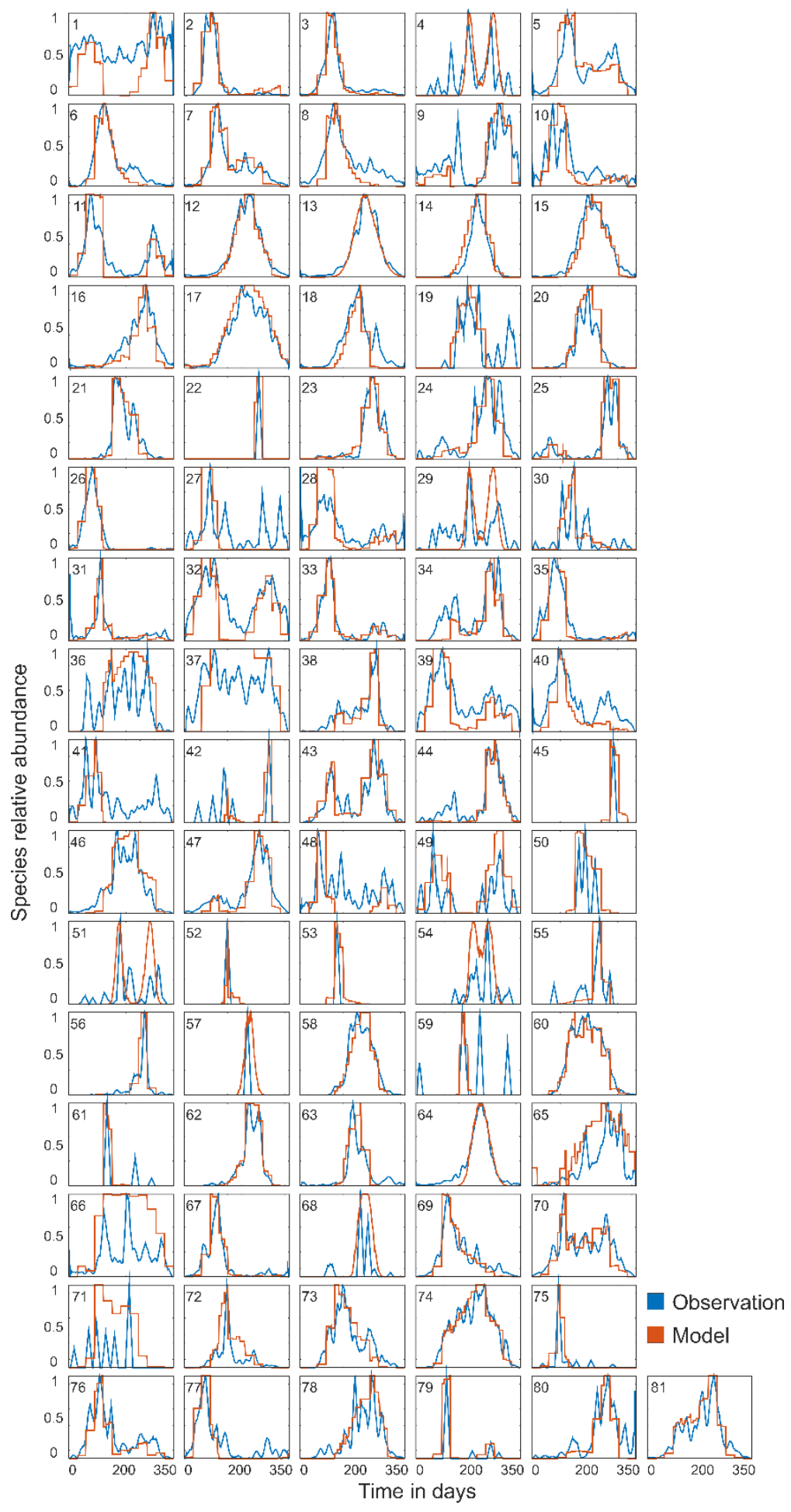

822 


\section{$824 \quad$ Figure 6.}

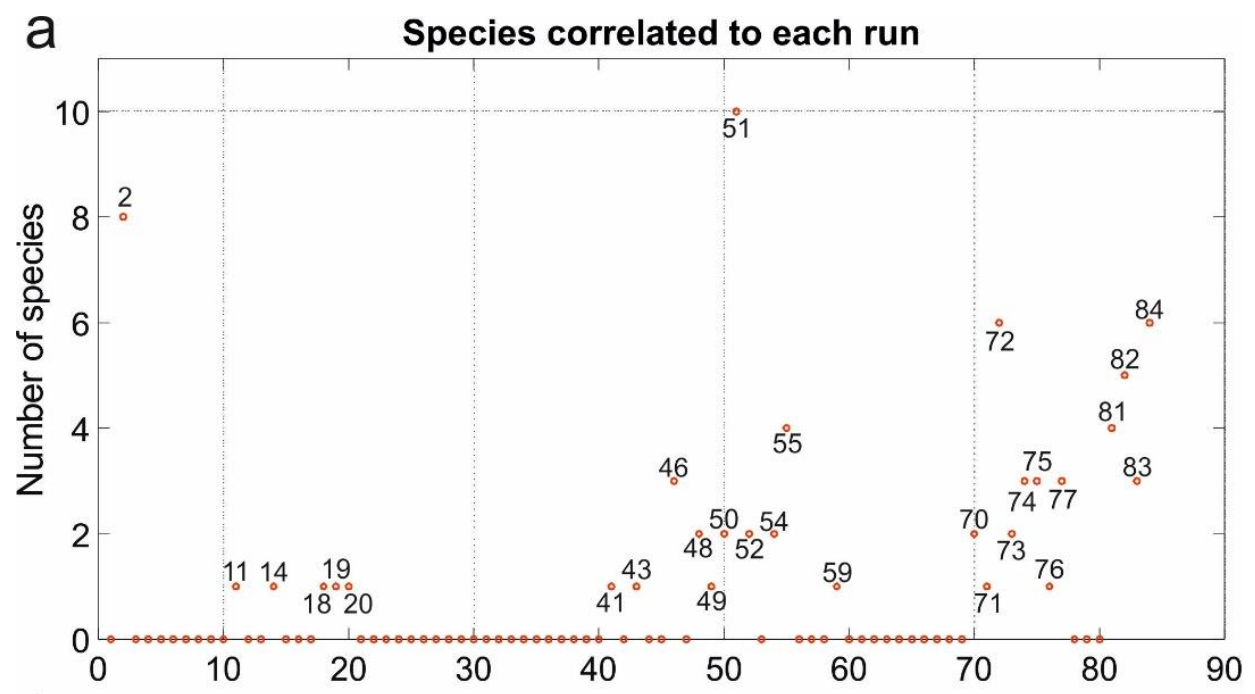

825

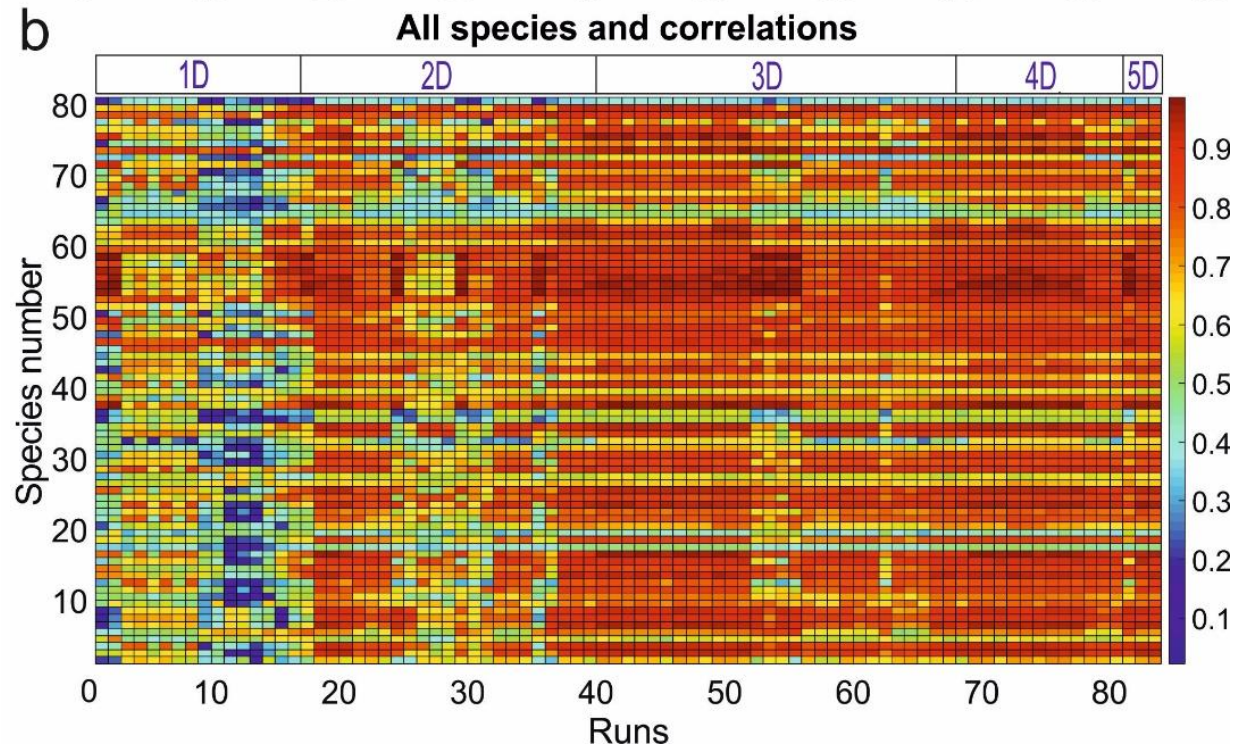

826

827

828

829

830

831

832

833

834

835 
Supporting Information

\section{Annual phytoplankton succession results from niche-environment interaction}

${ }^{2}$ Centre National de la Recherche Scientifique (CNRS), Université de Lille, Université Littoral Côte d'Opale, UMR 8187 LOG, Laboratoire d'Océanologie et de Géosciences, F 62930 Wimereux, France.

${ }^{3}$ Université de Lille, CNRS, Univ. Littoral Côte d'Opale, UMR 8187, LOG, Laboratoire d'Océanologie et de Géosciences, F 62930 Wimereux, France.

${ }^{4}$ Marine Biological Association, Continuous Plankton Recorder (CPR) survey, Citadel Hill, Plymouth PL1 2PB, UK.

${ }^{5}$ University of Plymouth, School of Biological and Marine Sciences, Drake Circus, Plymouth, $\mathrm{UK}$.
${ }^{6}$ Unité Biologie des organismes et écosystèmes aquatiques (BOREA), Muséum National d'Histoire Naturelle, Sorbonne Université, Université de Caen Normandie, Université des Antilles, CNRS, IRD, CP53, 61, Rue Buffon 75005 Paris, France.

Corresponding authors: Mariarita Caracciolo (mariarita.caracciolo@sb-roscoff.fr) and Gregory Beaugrand (Gregory.Beaugrand@univ-lille1.fr) 
Supplementary Figures and Tables Legends

865 Figure S1. Location of the study area. The geographical boundary of the rectangle (black box)

Figure S2. Thermal niche (bottom) and the associated theoretical response (top) of a hypothetical species to the fluctuations of an environmental parameter. The optimal value $\left(\mathrm{x}_{\mathrm{opt}}\right)$ of the ecological niche corresponds to the centre of the species' distributional range and is associated with the highest species' abundance that is located in the optimum zone between the two points $\mathrm{X}_{\mathrm{s}}$. The bimodal distribution of temporal variability exhibits a maximum $\mathrm{V}_{\max }$ corresponding to greatest slopes (XHV; HV for High Variability) of the niche. $\mathrm{X}_{\mathrm{D}}$ is the threshold from where environmental fluctuations are unlikely to be detected because the species' ecological sensitivity becomes too small. $\mathrm{X}_{\mathrm{L}}$ are the values where environmental variability becomes lethal. The grey areas indicate the region where the response of the species to environmental changes is expected to be strong. From Beaugrand and Kirby (2016).

Figure S3. Average correlation (a) and Mean Absolute Error (MAE) (b) for each run used to reconstruct annual phytoplankton succession from uni-dimensional (1D) to 5-dimensional (5D) models. The average value (blue circle) was based on the best correlations (a) or MAEs (b) assessed between observed species and (simulated) pseudo-species. Black and red points show the results of the same calculations based on a null model with (red) and without (black) consideration of temporal autocorrelation.

Table S1. List of phytoplankton species and their correlation with the first four principal components (PCs). List of phytoplankton species considered in our study area (see Fig. S1). The 81 species were grouped in the following classes: 1: Bacillariophyceae, 2: Dinophyceae, 3: Primnesiophyceae, 4: Dictyochophyceae and 5: Cyanophyceae. The first four PCs considered in Fig. 2 and their eigenvalues are reported here. A cross indicates a significant correlation $(>|0.5|)$ between a species and a principal component. Some species were not correlated. The percentage of explained variance per principal component is indicated into brackets. The seasonal cycles of each phytoplankton species are represented on Fig. S4 (see species numbers, first column of this table, for correspondence).

Table S2. Model simulations. Information on the 84 runs based on all possible combinations of environmental parameters from one (1D; uni-dimensional) to five (5D; 5-dimensional) variables. T: Sea Surface Temperature, Tbis: Sea Surface Temperature using a higher number of niches, PARa,b,c: Photosynthetically Active Radiation (the letters represent 3 different measures used to calculate the optimum values, E. $\mathrm{m}^{-2}$.day ${ }^{-1}$; see text and Table S3 for details), N: Nitrate ( $\mu$ mol.L$\left.{ }^{1}\right)$, S: Silicate $\left(\mu \mathrm{mol} . \mathrm{L}^{-1}\right), \mathrm{P}$ : Phosphate $\left(\mu \mathrm{mol} \mathrm{L}^{-1}\right), \mathrm{N} / \mathrm{P}$ : Nitrate/Phosphate ratio (see Table S3 for a better understanding of the selected SST and PAR values). For each run, computation time required for building pseudo-species and calculating species abundances is reported.

Table S3. Environmental variables used for the calculation of pseudo-species abundances and respective optimum and tolerance values. For each environmental parameter the table shows the different range of optimum values and ecological amplitudes defined for niche construction. We used several resolutions (first column) to calculate the environmental niche. For runs ended by "bis", the resolution was improved to examine model sensitivity related to the number of points used to calculate the niche. To examine the sensitivity of our analysis to PAR, 
910 three categories (a, b, c) were determined by selecting different minimum values (see text). When 911 more than one factor was considered, the number of niches was multiplied by each ecological 912 dimension to obtain the total number of niches (see text).

913

914 Table S4. Statistics calculated for the different runs, using several combinations of 915 environmental parameters. For each combination of environmental parameters, the number of 916 species, mean and maximum correlation values and probability values that result from the 917 application of null models for both the Pearson correlation and MAE, with and without 918 consideration of temporal autocorrelation, are reported. 
$920 \quad$ Figure S1.

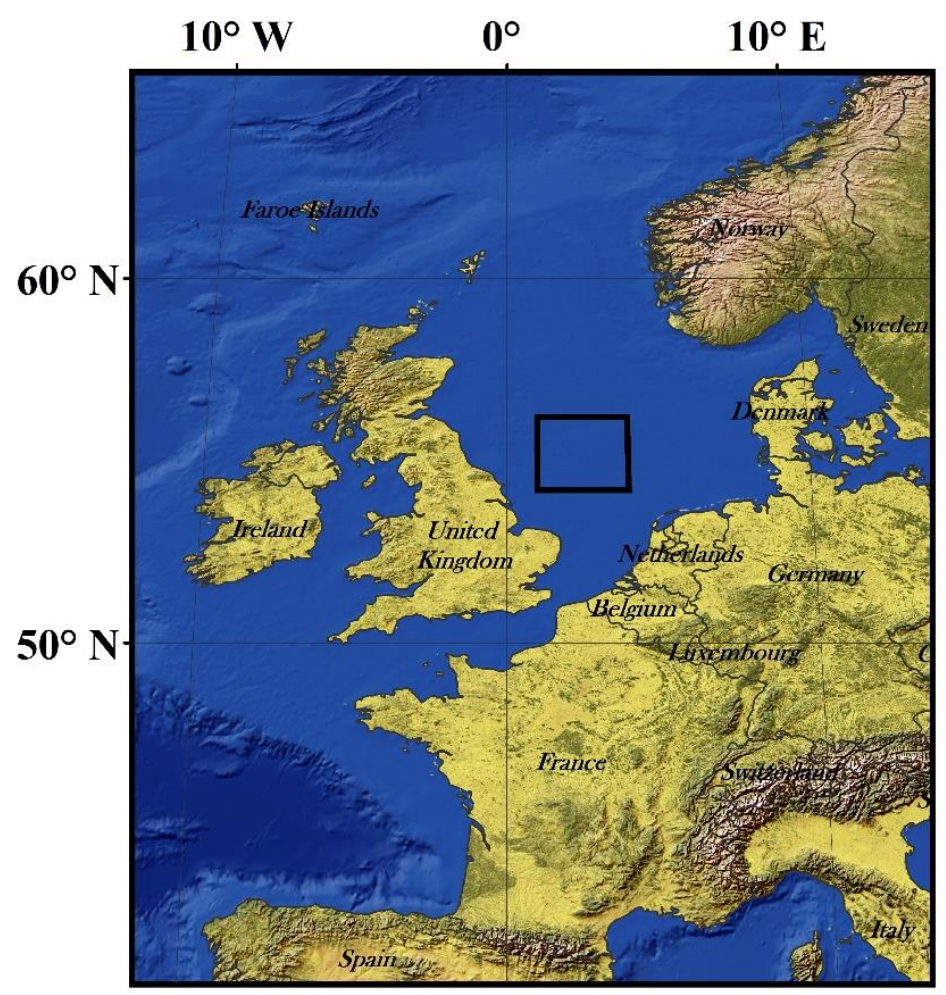

921

922 
923 Figure S2.

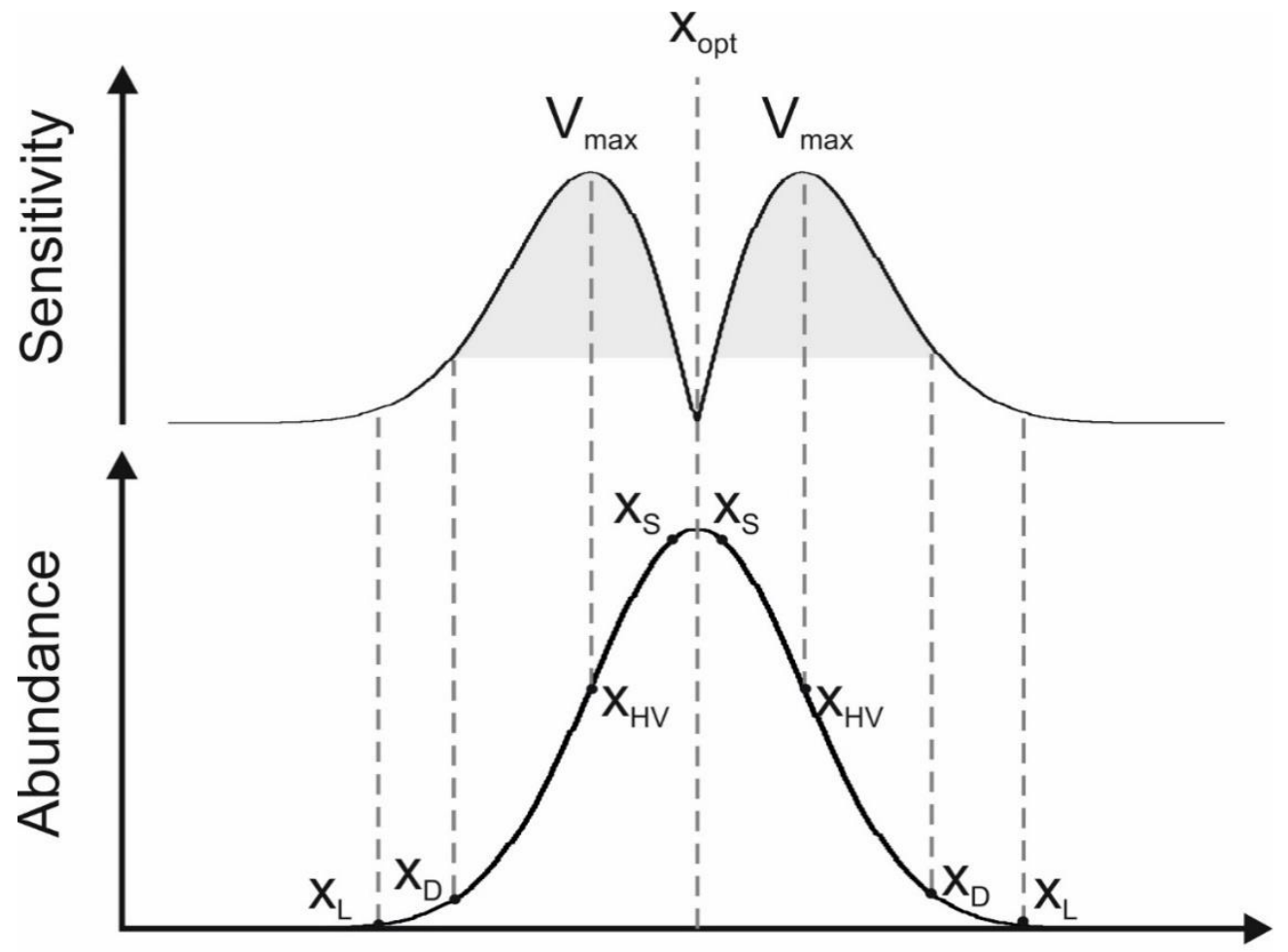

924

Environmental parameter

925 
a.

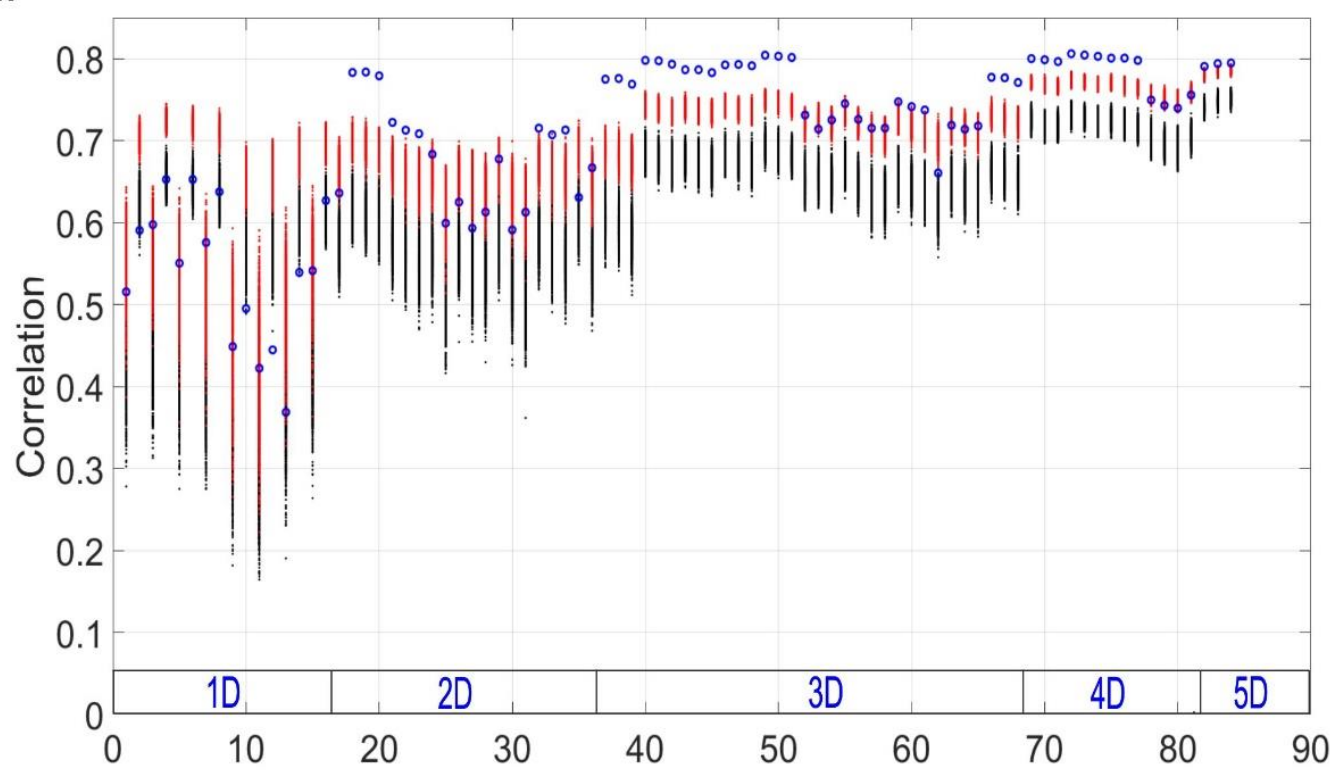

b.

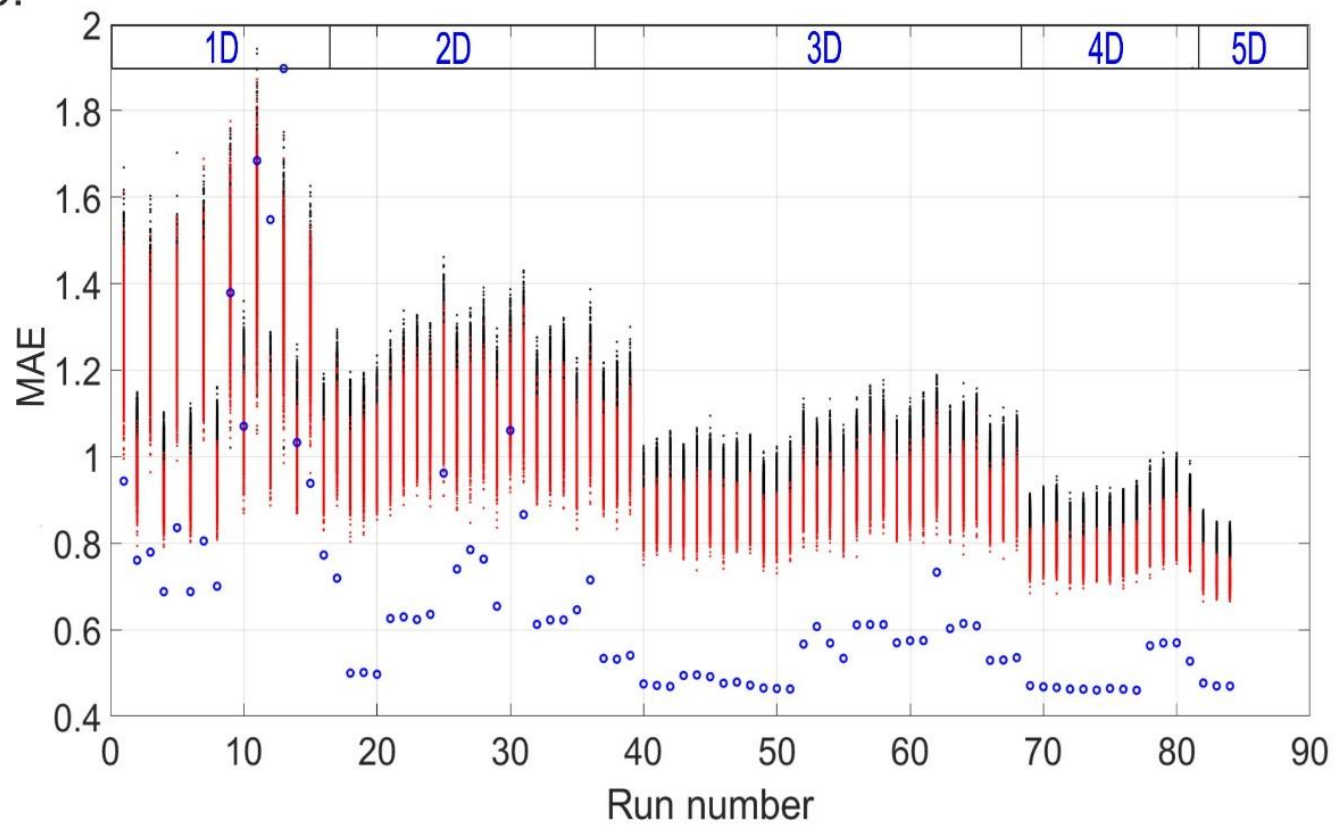




\section{$928 \quad$ Table S1.}

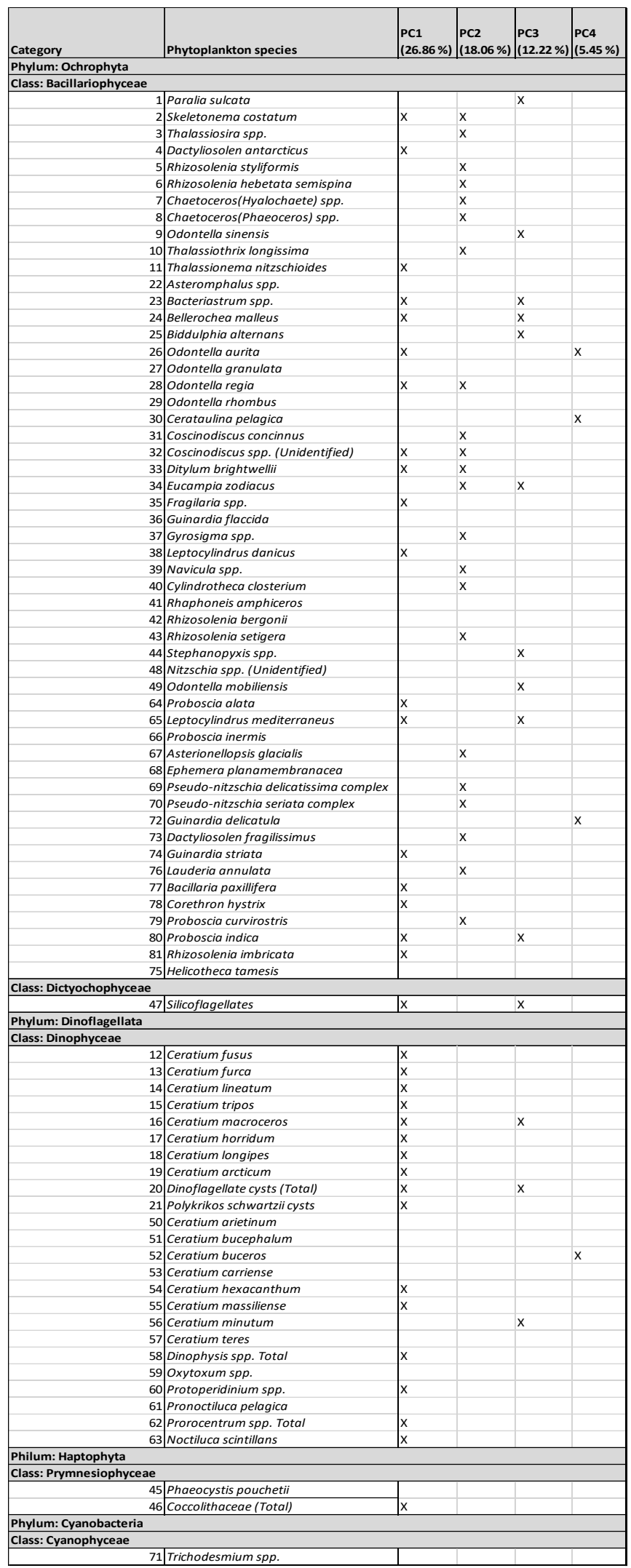




\section{$930 \quad$ Table S2.}

\begin{tabular}{|c|c|c|c|}
\hline Run $n^{\circ}$ & Dimension & Variable & $\begin{array}{c}\text { Computation } \\
\text { time (hh:mm:ss) }\end{array}$ \\
\hline Run 1 & $1 \mathrm{D}$ & $\mathrm{T}$ & 00:00:05 \\
\hline Run 2 & $1 \mathrm{D}$ & T bis & 00:00:08 \\
\hline Run 3 & $1 \mathrm{D}$ & PARa & 00:00:13 \\
\hline Run 4 & $1 \mathrm{D}$ & PARa bis & 00:00:17 \\
\hline Run 5 & $1 \mathrm{D}$ & PARb & $00: 00: 21$ \\
\hline Run 6 & $1 \mathrm{D}$ & PARb bis & 00:00:25 \\
\hline Run 7 & $1 \mathrm{D}$ & PARc & 00:00:05 \\
\hline Run 8 & $1 \mathrm{D}$ & PARc bis & 00:00:08 \\
\hline Run 9 & 1D & $\mathrm{N}$ & $00: 00: 05$ \\
\hline Run 10 & $1 \mathrm{D}$ & $\mathrm{N}$ bis & 00:00:08 \\
\hline Run 11 & 1D & $\mathrm{s}$ & 00:00:05 \\
\hline Run 12 & $1 \mathrm{D}$ & Sbis & $00: 00: 08$ \\
\hline Run 13 & $1 \mathrm{D}$ & $P$ & $00: 00: 05$ \\
\hline Run 14 & $1 \mathrm{D}$ & P bis & 00:00:08 \\
\hline Run 15 & 1D & $\mathrm{N} / \mathrm{P}$ & 00:00:05 \\
\hline Run 16 & 1D & $\mathrm{N} / \mathrm{P}$ bis & 00:00:08 \\
\hline Run 17 & $2 \mathrm{D}$ & $T$ and $N$ & 00:02:00 \\
\hline Run 18 & $2 \mathrm{D}$ & $T$ and PARa & 00:05:00 \\
\hline Run 19 & $2 \mathrm{D}$ & $T$ and PARb & 00:03:30 \\
\hline Run 20 & $2 \mathrm{D}$ & T and PARc & 00:02:00 \\
\hline Run 21 & $2 \mathrm{D}$ & $\mathrm{N}$ and PARa & 00:05:00 \\
\hline Run 22 & $2 \mathrm{D}$ & $\mathrm{N}$ and PARb & 00:03:30 \\
\hline Run 23 & $2 \mathrm{D}$ & $\mathrm{N}$ and PARc & 00:02:00 \\
\hline Run 24 & $2 \mathrm{D}$ & $T$ and $S$ & 00:02:00 \\
\hline Run 25 & $2 \mathrm{D}$ & $\mathrm{N}$ and $\mathrm{S}$ & 00:02:00 \\
\hline Run 26 & $2 \mathrm{D}$ & S and PARa & 00:05:00 \\
\hline Run 27 & $2 D$ & S and PARb & 00:03:30 \\
\hline Run 28 & $2 \mathrm{D}$ & S and PARc & 00:02:00 \\
\hline Run 29 & $2 \mathrm{D}$ & $T$ and $P$ & 00:02:00 \\
\hline Run 30 & $2 \mathrm{D}$ & $\mathrm{N}$ and $\mathrm{P}$ & 00:02:00 \\
\hline Run 31 & $2 \mathrm{D}$ & $S$ and $P$ & 00:02:00 \\
\hline Run 32 & $2 \mathrm{D}$ & P and PARa & 00:05:00 \\
\hline Run 33 & $2 \mathrm{D}$ & $P$ and PARb & 00:03:30 \\
\hline Run 34 & $2 \mathrm{D}$ & P and PARc & 00:02:00 \\
\hline Run 35 & $2 \mathrm{D}$ & $T$ and N/P & 00:02:00 \\
\hline Run 36 & $2 \mathrm{D}$ & $S$ and $N / P$ & 00:02:00 \\
\hline Run 37 & $2 D$ & $\mathrm{~N} / \mathrm{P}$ and PARa & 00:05:00 \\
\hline Run 38 & $2 \mathrm{D}$ & $\mathrm{N} / \mathrm{P}$ and $\mathrm{PARb}$ & 00:18:00 \\
\hline Run 39 & $2 \mathrm{D}$ & $\mathrm{N} / \mathrm{P}$ and PARC & 00:15:00 \\
\hline Run 40 & $3 \mathrm{D}$ & $\mathrm{T}, \mathrm{N}$ and PARa & $00: 20: 00$ \\
\hline Run 41 & $3 \mathrm{D}$ & $\mathrm{T}, \mathrm{N}$ and $\mathrm{PARb}$ & 00:18:00 \\
\hline Run 42 & $3 \mathrm{D}$ & $\mathrm{T}, \mathrm{N}$ and PARC & 00:15:00 \\
\hline Run 43 & $3 \mathrm{D}$ & $\mathrm{T}, \mathrm{S}$ and PARa & 00:20:00 \\
\hline Run 44 & $3 \mathrm{D}$ & $\mathrm{T}, \mathrm{S}$ and PARb & 00:18:00 \\
\hline Run 45 & $3 D$ & $\mathrm{~T}, \mathrm{~S}$ and PARC & 00:15:00 \\
\hline Run 46 & $3 D$ & $\mathrm{~T}, \mathrm{P}$ and PARa & 00:20:00 \\
\hline Run 47 & $3 \mathrm{D}$ & $\mathrm{T}, \mathrm{P}$ and PARb & 00:18:00 \\
\hline Run 48 & $3 D$ & $\mathrm{~T}, \mathrm{P}$ and PARC & 00:15:00 \\
\hline Run 49 & $3 \mathrm{D}$ & $\mathrm{T}, \mathrm{N} / \mathrm{P}$ and PARa & 00:20:00 \\
\hline Run 50 & $3 \mathrm{D}$ & $\mathrm{T}, \mathrm{N} / \mathrm{P}$ and PARb & $00: 18: 00$ \\
\hline Run 51 & $3 D$ & $\mathrm{~T}, \mathrm{~N} / \mathrm{P}$ and $\mathrm{PARC}$ & 00:15:00 \\
\hline Run 52 & $3 D$ & $\mathrm{~T}, \mathrm{~N}$ and $\mathrm{S}$ & 00:15:00 \\
\hline Run 53 & $3 \mathrm{D}$ & $T, N$ and $P$ & 00:15:00 \\
\hline Run 54 & $3 \mathrm{D}$ & $T, S$ and $P$ & 00:15:00 \\
\hline Run 55 & $3 \mathrm{D}$ & $\mathrm{T}, \mathrm{S}$ and $\mathrm{NP}$ & $00: 15: 00$ \\
\hline Run 56 & $3 D$ & $\mathrm{~N}, \mathrm{~S}$ and PARa & 00:20:00 \\
\hline Run 57 & $3 D$ & $\mathrm{~N}, \mathrm{~S}$ and $\mathrm{PARb}$ & $00: 18: 00$ \\
\hline Run 58 & $3 D$ & $\mathrm{~N}, \mathrm{~S}$ and PARC & 00:15:00 \\
\hline Run 59 & $3 \mathrm{D}$ & $\mathrm{N}, \mathrm{P}$ and PARa & $00: 20: 00$ \\
\hline Run 60 & $3 \mathrm{D}$ & $\mathrm{N}, \mathrm{P}$ and PARb & 00:18:00 \\
\hline Run 61 & $3 \mathrm{D}$ & $\mathrm{N}, \mathrm{P}$ and $\mathrm{PARc}$ & 00:15:00 \\
\hline Run 62 & $3 \mathrm{D}$ & $\mathrm{N}, \mathrm{S}$ and $\mathrm{P}$ & 00:15:00 \\
\hline Run 63 & $3 \mathrm{D}$ & $\mathrm{S}, \mathrm{P}$ and PARa & 00:20:00 \\
\hline Run 64 & $3 \mathrm{D}$ & $\mathrm{S}, \mathrm{P}$ and PARb & $00: 18: 00$ \\
\hline Run 65 & $3 \mathrm{D}$ & $\mathrm{S}, \mathrm{P}$ and PARC & 00:15:00 \\
\hline Run 66 & $3 \mathrm{D}$ & $\mathrm{S}, \mathrm{N} / \mathrm{P}$ and PARa & 00:20:00 \\
\hline Run 67 & $3 \mathrm{D}$ & $\mathrm{S}, \mathrm{N} / \mathrm{P}$ and PARb & 00:18:00 \\
\hline Run 68 & $3 D$ & $\mathrm{~S}, \mathrm{~N} / \mathrm{P}$ and $\mathrm{PARc}$ & 00:15:00 \\
\hline Run 69 & $4 \mathrm{D}$ & $\mathrm{T}, \mathrm{N}, \mathrm{S}, \mathrm{PARa}$ & 96:00:00 \\
\hline Run 70 & $4 \mathrm{D}$ & $\mathrm{T}, \mathrm{N}, \mathrm{S}, \mathrm{PARb}$ & $72: 00: 00$ \\
\hline Run 71 & $4 \mathrm{D}$ & $\mathrm{T}, \mathrm{N}, \mathrm{S}, \mathrm{PARC}$ & 60:00:00 \\
\hline Run 72 & $4 \mathrm{D}$ & $\mathrm{T}, \mathrm{N} / \mathrm{P}, \mathrm{PARa}, \mathrm{S}$ & 120:00:00 \\
\hline Run 73 & $4 \mathrm{D}$ & $\mathrm{T}, \mathrm{N} / \mathrm{P}, \mathrm{PARb}, \mathrm{S}$ & 96:00:00 \\
\hline Run 74 & $4 \mathrm{D}$ & $T, N / P, P A R c, S$ & 72:00:00 \\
\hline Run 75 & $4 \mathrm{D}$ & $\mathrm{T}, \mathrm{N}, \mathrm{P}, \mathrm{PARa}$ & 36:00:00 \\
\hline Run 76 & $4 \mathrm{D}$ & $T, N, P, P A R b$ & 36:00:00 \\
\hline Run 77 & $4 \mathrm{D}$ & $T, N, P, P A R c$ & $24: 00: 00$ \\
\hline Run 78 & $4 \mathrm{D}$ & $\mathrm{S}, \mathrm{N}, \mathrm{P}, \mathrm{PARa}$ & $60: 00: 00$ \\
\hline Run 79 & $4 \mathrm{D}$ & $\mathrm{S}, \mathrm{N}, \mathrm{P}, \mathrm{PARb}$ & 60:00:00 \\
\hline Run 80 & $4 \mathrm{D}$ & $\mathrm{S}, \mathrm{N}, \mathrm{P}, \mathrm{PARc}$ & 48:00:00 \\
\hline Run 81 & $4 \mathrm{D}$ & $\mathrm{T}, \mathrm{N}, \mathrm{S}, \mathrm{P}$ & 48:00:00 \\
\hline Run 82 & $5 \mathrm{D}$ & $\mathrm{T}, \mathrm{N}, \mathrm{S}, \mathrm{P}, \mathrm{PARC}$ & 480:00:00 \\
\hline Run 83 & $5 \mathrm{D}$ & $\mathrm{T}, \mathrm{N}, \mathrm{S}, \mathrm{P}, \mathrm{PARb}$ & $\begin{array}{l}984: 00: 00 \\
\end{array}$ \\
\hline Run 84 & $5 \mathrm{D}$ & $\mathrm{T}, \mathrm{N}, \mathrm{S}, \mathrm{P}, \mathrm{PARa}$ & 1176:00:00 \\
\hline
\end{tabular}


932 


\section{Table S3}

\begin{tabular}{|c|c|c|c|c|c|}
\hline Environmental variable & Optimum & $\begin{array}{c}\text { Number of } \\
\text { optimum } \\
\text { values }\end{array}$ & Tolerance & $\begin{array}{c}\text { Number of } \\
\text { ecological } \\
\text { amplitudes }\end{array}$ & $\begin{array}{l}\text { Number } \\
\text { of niches }\end{array}$ \\
\hline Temperature $=-2,-1,0, \ldots, 44$ & $0,6,12, \ldots, 36$ & 7 & $1,4,7,10$ & 4 & 28 \\
\hline Temperature bis $=-2,1.99,1.98, \ldots, 44$ & $0,1,2, \ldots, 40$ & 41 & $1,2,3, \ldots, 40$ & 10 & 410 \\
\hline PARa $=0,1,2, \ldots, 70$ & $1,9,17, \ldots, 70$ & 9 & $1,5,9$ & 3 & 27 \\
\hline PARa bis $=0,0.25,0.50, \ldots, 70$ & $1,2,3, \ldots, 70$ & 70 & $1,2,3, \ldots, 9$ & 9 & 630 \\
\hline PARb $=0,1,2, \ldots, 70$ & $10,18,26, \ldots, 70$ & 8 & $1,5,9$ & 3 & 24 \\
\hline PARb bis $=0,0.25,0.50, \ldots, 70$ & $10,11,12, \ldots, 70$ & 60 & $1,2,3, \ldots, 9$ & 9 & 540 \\
\hline PARc $=0,1,2, \ldots, 70$ & $20,28,36, \ldots, 70$ & 7 & $1,5,9$ & 3 & 21 \\
\hline PARc bis $=0,0.25,0.50, \ldots, 70$ & $20,21,22 \ldots, 70$ & 50 & $1,2,3, \ldots, 9$ & 9 & 450 \\
\hline Nitrate $=0,1,2, \ldots, 43$ & $1,6,11, \ldots, 41$ & 9 & $1,4,7$ & 3 & 27 \\
\hline Nitrate bis $=0,0.01,0.02, \ldots, 43$ & $1,2,3, \ldots, 41$ & 41 & $1,2,3, \ldots, 7$ & 7 & 287 \\
\hline Silicate $=0,1,2, \ldots, 127$ & $1,20,39, \ldots, 126$ & 7 & $1,6,11,16$ & 4 & 28 \\
\hline Silicate bis $=0,0.1,0.2, \ldots, 127$ & $1,4,7, \ldots, 126$ & 42 & $1,2,3, \ldots, 16$ & 16 & 672 \\
\hline Phosphate $=0,0.1,0.2, \ldots, 3.8$ & $0.1,0.4,3.5$ & 3 & $0.1,0.3,0.5$ & 3 & 27 \\
\hline Phosphate bis $=0,0.01,0.02, \ldots, 3.8$ & $0.1,0.2,0.3, \ldots, 3.5$ & 35 & $0.1,0.13,0.16, \ldots, 0.5$ & 16 & 560 \\
\hline $\mathrm{N} / \mathrm{P}=0,0.2,0.4, \ldots, 25$ & $0,4,8, \ldots, 24$ & 7 & $1,2,3,4$ & 4 & 28 \\
\hline N/P bis $=0,0.01,0.02, \ldots, 25$ & $0,1,2, \ldots, 24$ & 25 & $1,1.25,1.50, \ldots, 4$ & 16 & 400 \\
\hline
\end{tabular}

934

N/P bis $=0,0.01,0.02, \ldots, 25$

935

936 


\section{$937 \quad$ Table S4.}

\begin{tabular}{|c|c|c|c|c|c|c|c|c|}
\hline & & Phytoplankton & & & Null model & Null model & Null model & Null model \\
\hline & & & & & Correlation & Correlation & MAE & MAE \\
\hline & & & & & $\begin{array}{c}\text { Without } \\
\text { autocorrelation }\end{array}$ & $\begin{array}{c}\text { With } \\
\text { autocorrelation }\end{array}$ & \begin{tabular}{c|} 
Without \\
autocorrelation
\end{tabular} & $\begin{array}{c}\text { With } \\
\text { autocorrelation }\end{array}$ \\
\hline Run $n^{\circ}$ & Parameters & $\begin{array}{c}\text { Mean } \\
\text { correlation }\end{array}$ & $\begin{array}{c}\text { Species } \\
\text { correlated }\end{array}$ & $\begin{array}{c}\begin{array}{c}\text { Highest } \\
\text { correlations }\end{array} \\
\text { (a) }\end{array}$ & Probability & Probability & Probability & Probability \\
\hline Run 1 & $\mathrm{~T}$ & 0,5156 & 0 & - & 2,8 & 83,8 & 0 & 0 \\
\hline Run 2 & T.bis & 0,5906 & 8 & 0,7676 & 98,3 & 100 & 0 & 0 \\
\hline Run 3 & $\begin{array}{l}\text { PARa } \\
\end{array}$ & 0,5976 & 0 & - & 0 & 15,7 & 0 & 0 \\
\hline Run 4 & PARa.bis & 0,6527 & 0 & - & 59,4 & 100 & 0 & 0 \\
\hline Run 5 & PARb & 0,5506 & 0 & - & 0,1 & 49,3 & 0 & 0 \\
\hline Run 6 & PARb.bis & 0,6527 & 0 & - & 33,9 & 100 & 0 & 0 \\
\hline Run 7 & PARc & 0,5757 & 0 & - & 0 & 12,3 & 0 & 0 \\
\hline Run 8 & PARc.bis & 0,6376 & 0 & - & 42,9 & 100 & 0 & 0 \\
\hline \begin{tabular}{|l|} 
Run 9 \\
\end{tabular} & $\mathrm{~N}$ & 0,4488 & 0 & - & 3,1 & 66,6 & 24,5 & 46,5 \\
\hline Run 10 & N.bis & 0,4951 & 0 & - & 99,7 & 100 & 5,4 & 55,8 \\
\hline Run 11 & $\mathrm{~s}$ & 0,4224 & 1 & 0,6937 & 3,9 & 52 & 88,4 & 94,7 \\
\hline Run 12 & S.bis & 0,4447 & 0 & - & 100 & 100 & 100 & 100 \\
\hline Run 13 & $P$ & 0,3687 & 0 & - & 61,3 & 99 & 100 & 100 \\
\hline Run 14 & P.bis & 0,5392 & 1 & 0,6318 & 99,8 & 100 & 7,6 & 77,5 \\
\hline Run 15 & $\mathrm{~N} / \mathrm{P}$ & 0,5414 & 0 & - & 0,2 & 62,1 & 0 & 0 \\
\hline Run 16 & N/P.bis & 0,6270 & 0 & - & 25,7 & 100 & 0 & 0 \\
\hline Run 17 & $T$ and $\mathrm{N}$ & 0,6362 & 0 & - & 0,1 & 98,8 & 0 & 0 \\
\hline Run 18 & T and PARa & 0,7833 & 1 & 0,8790 & 0 & 0 & 0 & 0 \\
\hline Run 19 & T and PARb & 0,7838 & 1 & 0,8344 & 0 & 0 & 0 & 0 \\
\hline Run 20 & T and PARC & 0,7791 & 1 & 0,7589 & 0 & 0 & 0 & 0 \\
\hline Run 21 & $\mathrm{N}$ and PARa & 0,7224 & 0 & - & 0 & 0 & 0 & 0 \\
\hline Run 22 & $\mathrm{~N}$ and PARb & 0,7128 & 0 & - & 0 & 0 & 0 & 0 \\
\hline Run 23 & $\mathrm{~N}$ and PARc & 0,7085 & 0 & - & 0 & 0 & 0 & 0 \\
\hline Run 24 & $T$ and $S$ & 0,6835 & 0 & - & 0 & 3,9 & 0 & 0 \\
\hline Run 25 & $\mathrm{~N}$ and $\mathrm{S}$ & 0,5993 & 0 & - & 0,1 & 77,7 & 0 & 0,7 \\
\hline Run 26 & S and PARa & 0,6251 & 0 & - & 0,2 & 98,6 & 0 & 0 \\
\hline Run 27 & S and PARb & 0,5933 & 0 & - & 3,2 & 99,9 & 0 & 0 \\
\hline Run 28 & S and PARC & 0,6129 & 0 & - & 0,2 & 93,1 & 0 & 0 \\
\hline Run 29 & $\mathrm{~T}$ and $\mathrm{P}$ & 0,6776 & 0 & - & 0 & 28,9 & 0 & 0 \\
\hline Run 30 & $\mathrm{~N}$ and $\mathrm{P}$ & 0,5912 & 0 & - & 0,9 & 98,5 & 1,5 & 19,1 \\
\hline Run 31 & $S$ and $P$ & 0,6127 & 0 & - & 0,1 & 66,7 & 0 & 0 \\
\hline Run 32 & $P$ and PARa & 0,7153 & 0 & - & 0 & 0 & 0 & 0 \\
\hline Run 33 & P and PARb & 0,7073 & 0 & - & 0 & 0,1 & 0 & 0 \\
\hline Run 34 & $P$ and PARc & 0,7130 & 0 & - & 0 & 0 & 0 & 0 \\
\hline Run 35 & T and N/P & 0,6308 & 0 & - & 8,4 & 100 & 0 & 0 \\
\hline Run 36 & $S$ and $N / P$ & 0,6670 & 0 & - & 0 & 17,4 & 0 & 0 \\
\hline Run 37 & $\mathrm{~N} / \mathrm{P}$ and PARa & 0,7751 & 0 & - & 0 & 0 & 0 & 0 \\
\hline Run 38 & $\mathrm{~N} / \mathrm{P}$ and PARb & 0,7759 & 0 & - & 0 & 0 & 0 & 0 \\
\hline Run 39 & $\mathrm{~N} / \mathrm{P}$ and PARc & 0,7690 & 0 & - & 0 & 0 & 0 & 0 \\
\hline Run 40 & $\mathrm{T}, \mathrm{N}$ and PARa & 0,7981 & 0 & - & 0 & 0 & 0 & 0 \\
\hline Run 41 & $\mathrm{T}, \mathrm{N}$ and $\mathrm{PARb}$ & 0,7975 & 1 & 0,8276 & 0 & 0 & 0 & 0 \\
\hline Run 42 & $\mathrm{T}, \mathrm{N}$ and PARC & 0,7934 & 0 & - & 0 & 0 & 0 & 0 \\
\hline Run 43 & $\mathrm{T}, \mathrm{S}$ and PARa & 0,7866 & 1 & 0,9613 & 0 & 0 & 0 & 0 \\
\hline Run 44 & $\mathrm{T}, \mathrm{S}$ and PARb & 0,7866 & 0 & - & 0 & 0 & 0 & 0 \\
\hline Run 45 & $\mathrm{T}, \mathrm{S}$ and PARC & 0,7831 & 0 & - & 0 & 0 & 0 & 0 \\
\hline Run 46 & $\mathrm{T}, \mathrm{P}$ and PARa & 0,7925 & 3 & 0,9384 & 0 & 0 & 0 & 0 \\
\hline Run 47 & $\mathrm{T}, \mathrm{P}$ and $\mathrm{PARb}$ & 0,7931 & 0 & - & 0 & 0 & 0 & 0 \\
\hline Run 48 & T,P and PARc & 0,7915 & 2 & 0,9162 & 0 & 0 & 0 & 0 \\
\hline Run 49 & $\mathrm{T}, \mathrm{N} / \mathrm{P}$ and PARa & 0,8043 & 1 & 0,8913 & 0 & 0 & 0 & 0 \\
\hline Run 50 & $\mathrm{~T}, \mathrm{~N} / \mathrm{P}$ and PARb & 0,8031 & 2 & 0,7807 & 0 & 0 & 0 & 0 \\
\hline Run 51 & $\mathrm{T}, \mathrm{N} / \mathrm{P}$ and $\mathrm{PARc}$ & 0,8016 & 10 & 0,8644 & 0 & 0 & 0 & 0 \\
\hline Run 52 & $\mathrm{T}, \mathrm{N}$ and $\mathrm{S}$ & 0,7313 & 2 & 0,8896 & 0 & 7,9 & 0 & 0 \\
\hline Run 53 & $T, N$ and $P$ & 0,7142 & 0 & - & 0 & 97,8 & 0 & 0 \\
\hline Run 54 & $\mathrm{T}, \mathrm{S}$ and $\mathrm{P}$ & 0,7253 & 2 & 0,9691 & 0 & 34,2 & 0 & 0 \\
\hline Run 55 & $\mathrm{~T}, \mathrm{~S}$ and $\mathrm{NP}$ & 0,7452 & 4 & 0,8548 & 0 & 4,7 & 0 & 0 \\
\hline Run 56 & $\mathrm{N}, \mathrm{S}$ and PARa & 0,7261 & 0 & - & 0 & 24,3 & 0 & 0 \\
\hline $\begin{array}{l}\text { Run } 57 \\
\end{array}$ & $\mathrm{~N}, \mathrm{~S}$ and PARb & 0,7154 & 0 & - & 0 & 19,6 & 0 & 0 \\
\hline Run 58 & $\mathrm{~N}, \mathrm{~S}$ and PARC & 0,7154 & 0 & - & 0 & 21,5 & 0 & 0 \\
\hline Run 59 & $\mathrm{N}, \mathrm{P}$ and PARa & 0,7475 & 1 & 0,4239 & 0 & 0,1 & 0 & 0 \\
\hline Run 60 & $\mathrm{~N}, \mathrm{P}$ and $\mathrm{PARb}$ & 0,7415 & 0 & - & 0 & 0,1 & 0 & 0 \\
\hline Run 61 & $\mathrm{~N}, \mathrm{P}$ and PARc & 0,7374 & 0 & - & 0 & 0 & 0 & 0 \\
\hline Run 62 & $\mathrm{~N}, \mathrm{~S}$ and $\mathrm{P}$ & 0,6605 & 0 & - & 0,1 & 100 & 0 & 0 \\
\hline Run 63 & $\mathrm{~S}, \mathrm{P}$ and PARa & 0,7189 & 0 & - & 0 & 53,8 & 0 & 0 \\
\hline Run 64 & $\mathrm{~S}, \mathrm{P}$ and $\mathrm{PARb}$ & 0,7141 & 0 & - & 0 & 53,4 & 0 & 0 \\
\hline Run 65 & $S, P$ and PARc & 0,7180 & 0 & - & 0 & 14,8 & 0 & 0 \\
\hline Run 66 & S,N/P and PARa & 0,7774 & 0 & - & 0 & 0 & 0 & 0 \\
\hline Run 67 & $\mathrm{~S}, \mathrm{~N} / \mathrm{P}$ and PARb & 0,7767 & 0 & - & 0 & 0 & 0 & 0 \\
\hline Run 68 & $\mathrm{~S}, \mathrm{~N} / \mathrm{P}$ and PARc & 0,7710 & 0 & - & 0 & 0 & 0 & 0 \\
\hline Run 69 & T, N, S, PARa & 0,8002 & 0 & - & 0 & 0 & 0 & 0 \\
\hline Run 70 & $\mathrm{~T}, \mathrm{~N}, \mathrm{~S}, \mathrm{PARb}$ & 0,7988 & 2 & 0,8240 & 0 & 0 & 0 & 0 \\
\hline Run 71 & $\mathrm{T}, \mathrm{N}, \mathrm{S}, \mathrm{PARC}$ & 0,7966 & 1 & 0,9490 & 0 & 0 & 0 & 0 \\
\hline Run 72 & $T, N P, P A R a, S$ & 0,8062 & 6 & 0,8390 & 0 & 0 & 0 & 0 \\
\hline Run 73 & $T, N P, P A R b, S$ & 0,8045 & 2 & 0,8274 & 0 & 0 & 0 & 0 \\
\hline Run 74 & $\mathrm{~T}, \mathrm{NP}, \mathrm{PARc}, \mathrm{S}$ & 0,8030 & 3 & 0,7431 & 0 & 0 & 0 & 0 \\
\hline Run 75 & $\mathrm{~T}, \mathrm{~N}, \mathrm{P}, \mathrm{PARa}$ & 0,8008 & 3 & 0,8920 & 0 & 0 & 0 & 0 \\
\hline Run 76 & $T, N, P, P A R b$ & 0,8008 & 1 & 0,7896 & 0 & 0 & 0 & 0 \\
\hline Run 77 & $\mathrm{~T}, \mathrm{~N}, \mathrm{P}, \mathrm{PARC}$ & 0,7980 & 3 & 0,8575 & 0 & 0 & 0 & 0 \\
\hline Run 78 & $\mathrm{~S}, \mathrm{~N}, \mathrm{P}, \mathrm{PARa}$ & 0,7497 & 0 & - & 0 & 90,8 & 0 & 0 \\
\hline Run 79 & $\mathrm{~S}, \mathrm{~N}, \mathrm{P}, \mathrm{PARb}$ & 0,7431 & 0 & - & 0 & 96 & 0 & 0 \\
\hline Run 80 & $\mathrm{~S}, \mathrm{~N}, \mathrm{P}, \mathrm{PARC}$ & 0,7397 & 0 & - & 0 & 97,1 & 0 & 0 \\
\hline Run 81 & $\mathrm{~T}, \mathrm{~N}, \mathrm{~S}, \mathrm{P}$ & 0,7558 & 4 & 0,8849 & 0 & 76,5 & 0 & 0 \\
\hline Run 82 & $T, N, S, P, P A R C$ & 0,7906 & 5 & 0,7922 & 0 & 0 & 0 & 0 \\
\hline Run 83 & T,N,S,P,PARb & 0,7941 & 3 & 0,8741 & 0 & 0 & 0 & 0 \\
\hline Run 84 & $\mathrm{~T}, \mathrm{~N}, \mathrm{~S}, \mathrm{P}, \mathrm{PARa}$ & 0,7948 & 6 & 0,8378 & 0 & 0 & 0 & 0 \\
\hline
\end{tabular}

